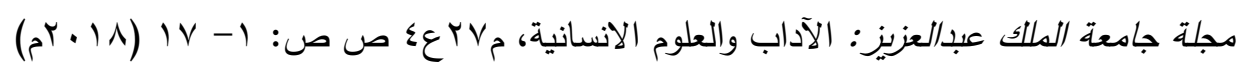

DOI:10.4197/Art.27-4.1

أثر استعمال الفقهاء لفظي الفاسد والباطل في العبادات على الفروع الفقهية

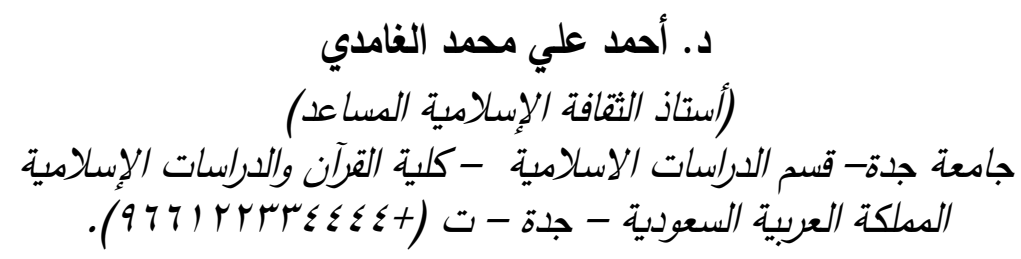

Ahmadksa1436@gmail.com

مستخلص. هذا البحث يتتاول الفرق بين الفاسد والباطل تتاولًا فقهيّا، ومرجحا فيه الباحث ما ظهر له بعد التحري والاستدلال،

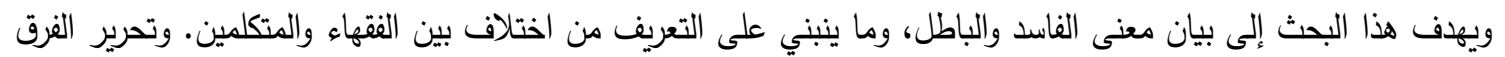

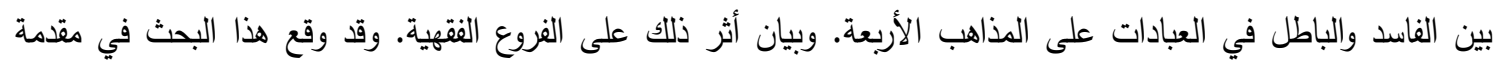

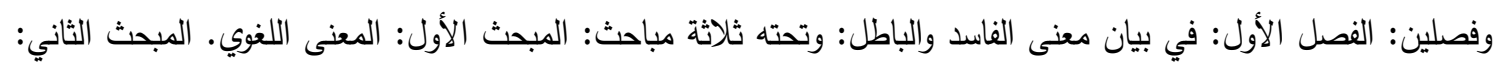

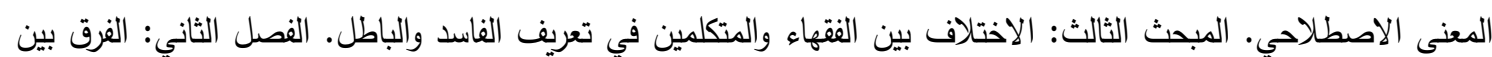
الفاسد والباطل عند الدذاهب الأربعة في جانب العبادات. وتحته ثلاثة مباحث: المبحث الأول: الفاسد والباطل عند الحنفية وأثره

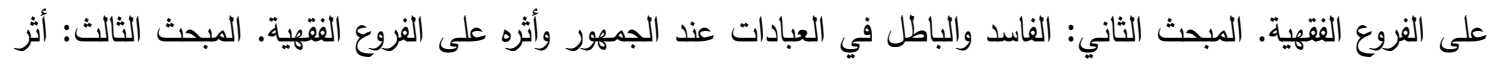

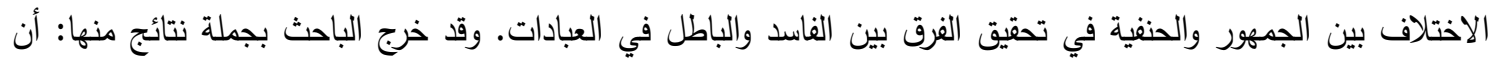
البحث للفاسد والباطل في المعنى الاصطلاحي عند الفقهاء والمتكلمين أمر منفصل عن الفرق بين الفاسد والباطل عند الحنفية وبقية الدذاهب الأربعة، وأن الخلاف بين المتكلمين والفقهاء للمعنى الاصطلاحي للفساد والبطلان هو خلاف معنوي ينبني عليه

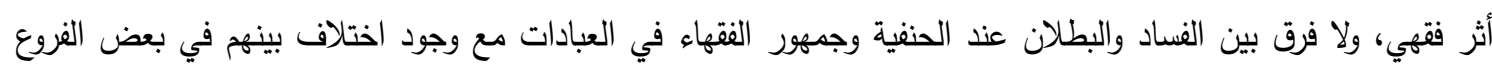
الكلمات المفتاحية الفاسد. الباطل. الفساد. البطلان. المتكلمين. الفقهاء.

السماوات، ولهجت بالذكر ألسنة الذاكرين والذاكرات.



فمن كرم المولى أن ينعم على العبد الفقير أن يكتب موضوعاً جمع فيه بين الأصول والفروع مغرقاً فيه بين أمرين لا يخل كتاب أصولي ولا فقهي من فن

\section{المقدمة}

الحمد الله الذي تتم بنعمه الصالحات، وبكرمه وفضله

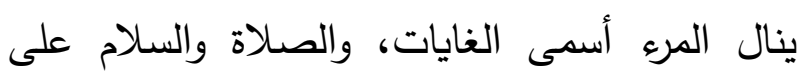
خاتم النبوات، والحائز على كريم السجايا والصفات، ولا غرو فهو دن أدّبه رب البريات، صلوات الله وسلامه عليه ما تتاغمت أصوات الأطيار في 
الدذاهب الأربعة كما سيتضح ذلك جليَّا خلال ثنايا البحث بإذن الله تعالى. وكذلك أذكر هنا رسالة ماجستير في جامعة أم القرى لثيخي الفاضل الدكتور جبريل مهدي حفظه الله

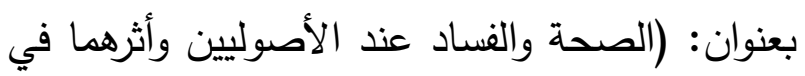
الفقه الإسلامي)، وهي رسالة قيّمة استفدت منها كثيراً في بحثي هذا، فجزاه الله خير الجزاء، والثيخ بارك فئل فئه

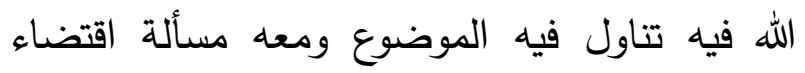
النهي النساد، كما هو الحال في الرسالة السابقة

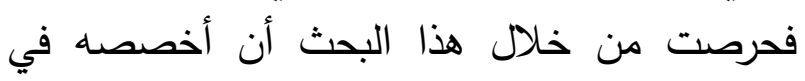

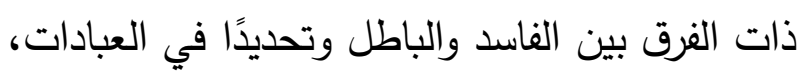

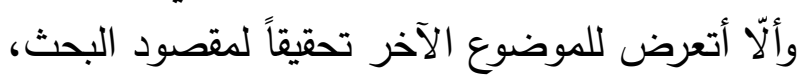
وتسهيلاً للقارئ حتى يكوّن تصوراً واضحاً وتقعيديّا

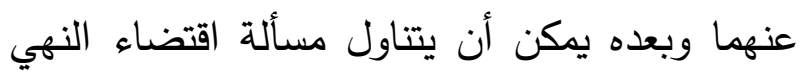
الفساد في موضعها؛ وهذا ما شكّل لي مشكلة في

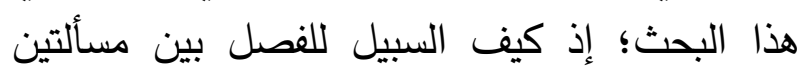

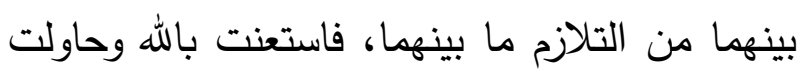

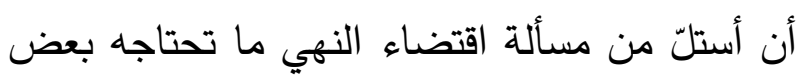

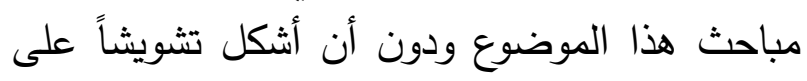
القارئ وارجو أن أكون وفقت في ذللك و الله المستعان.

\section{منهج البحث:}

سلكت في هذا البحث المنهج الاستقرائي التحليلي المقارن، وفيما يلي إيضاح لهذا المنهج: 1- كما يظهر من عنوان هذا البحث فالمقصود منه لهنه

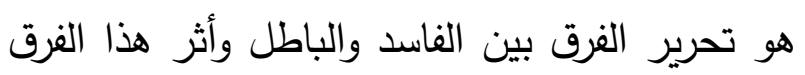

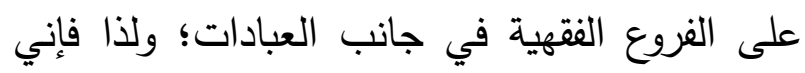
عند ذكر الفرق بينهما اكتفي غالباً بعرض الأقوال



إيرادهما؛ كيف لا وهما أحد طرفي نهاية الحكم' على الع

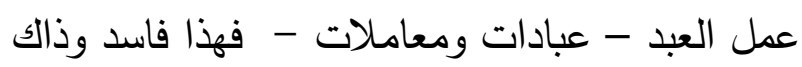
باطل؛ الأمر الذي يحتاج إليه طالب العلم عند مطالعة الكتب من تمييز الفرق بينهما ومعرفة التهاج حقيقتهما الشرعية واللغوية. ولقد اخترت أن يستقل هذا البحث بتحرير جوانب

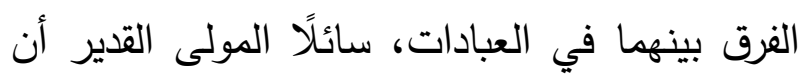

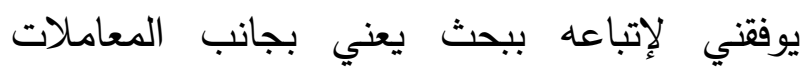
ليكتمل العقد. و الله العظيم أسأل أن يلهمني الصواب ويرزقني الإخلاص فيما أحرّره وأقرّره وأن يجعله نافعاً للباحث والقارئ وعلماً أنتفع به في الحرّ وآزره وان لحياة وبعد الممات.. اللهم آمين.

الاراسات السابقة تناولت بعض الدراسات الفرق بين الفاسد والباطل

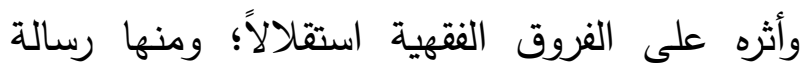
دكتوراه في الجامعة الأردنية للباحثة حنان يونس

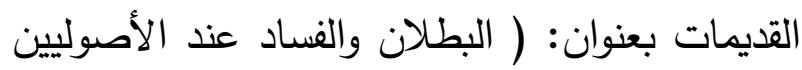

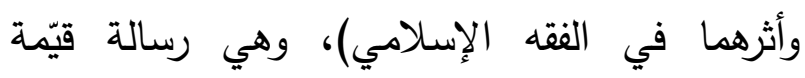

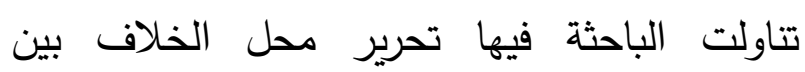
الأصوليين في الفرق بين البطلان والفساد وفي دلالة

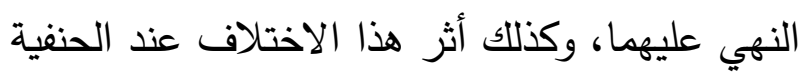
والجمهور في العبادات والمعاملات. وقيّ تميّز هذا البحث بذكر المعنى الاصطيلادي ولماتي للفاسد والباطل عند الفقهاء والمتكلمين كأمر منفصل لإنل عن مبحث الفساد والبطلان عند الحنفية وعند بقية كلية

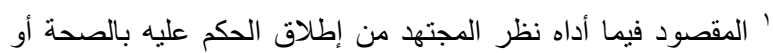

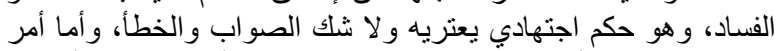

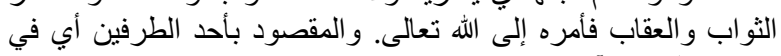

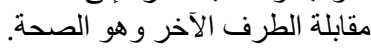


الفصل الثاني: الفرق بين الفاسد والباطل عند الدذاهب الأربعة في جانب العبادات. وتحته ثلاثة

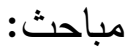
المبحث الأول: الفاسد والباطل في العبادات عند الحنفية وأثره على الفروع الفقهية. المبحث الثاني: الفاسد والباطل في العبادات عند الثراه الجمهور وأثره على الفروع الفقهية. المبحث الثالث: أثر الاختلاف بين الجمهور والحنفية في تحقيق الفرق بين الفاسد والباطل في العبادات.

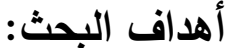
1.بيان معنى الفاسد والباطل وما ينبني على الفى التعريف من اختلاف بين الفقهاء والمتكلمين. r.تحرير الفرق بين الفاسد والباطل في العبادات

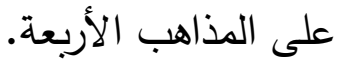
r.بيان أثر الفرق على الفروع الفقهية على المذاهب الفبها

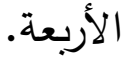

الفصل الأول: بيان معنى الفاسد والباطل:

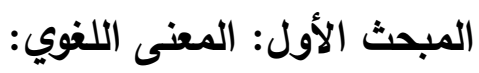
الفاسد لغة: أصل الكلمة فَسَد ، يفسُد ويفِيد. وفُسُد،

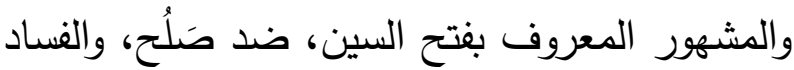

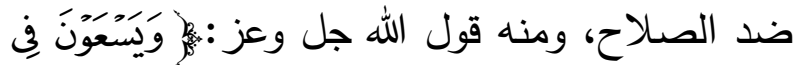

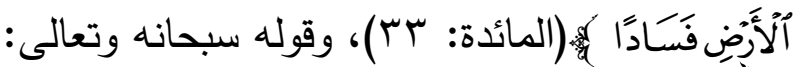

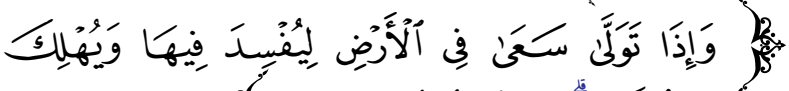

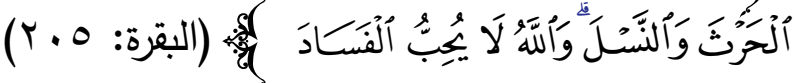

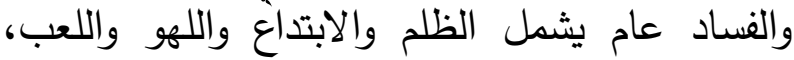

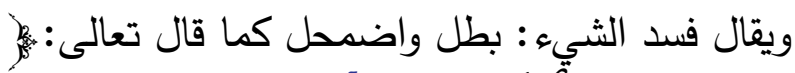

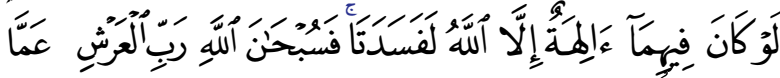

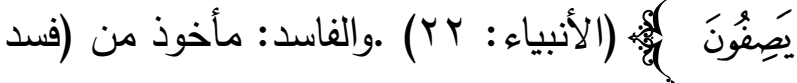

واختم ذلك بما يترجح لدي؛ إذ المقصود إثبات الفرق إن وجد وبيان أثر ذللك الفرق على الفروع الفقهية. r- المقصود ببيان أثر الفرق على الفروع الفقهية

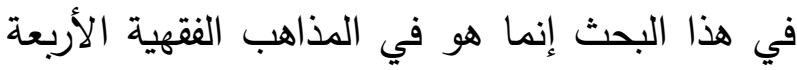
(الحنفية والمالكية والثافعية والحنابلة). r- عند عرض الخلاف في المسألة الفقهية أشير إلى الراجح لديّ بناء على ترجيح المسألة أصولياً

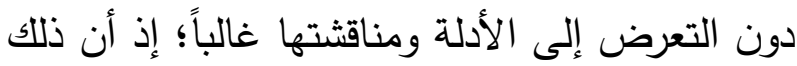
خارج مقصود هذا البحث كما تقدم.

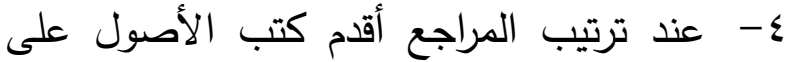

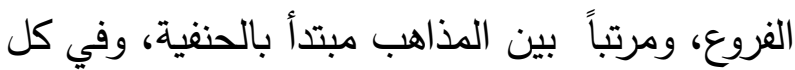
مذهب أرتبها على حسب تاريخ وفاة مصنفيها. 0- أشير إلى تخريج الحديث والحكم عليه اختصاراً

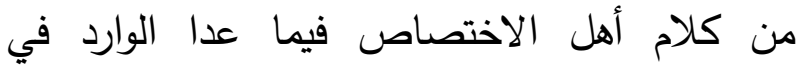
الصحيحين. 1- أذكر تعريفاً مختصراً للأعلام الوارد ذكرهم في

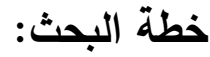
وقد جعلت هذا البحث في مقدمة وفصلين، وقسمت كل فصل إلى مباحث وهذا بيانه: الفصل الأول: بيان معنى الفاسد والباطل: وتحته

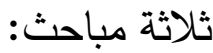
المبحث الأول: المعنى اللغوي.

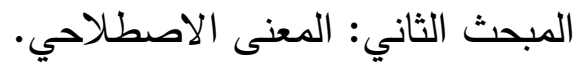
المبحث الثالث: الاختلاف بين الفقهاء والمتكلمين في تعريف الفاسد والباطل: 
القول الأول أبو الفيض الزَّبيديّ في تاج العروس.

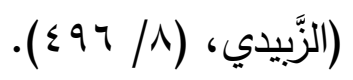

الترجيح: لعل الراجح - و الله أعلم - هو عدم التران

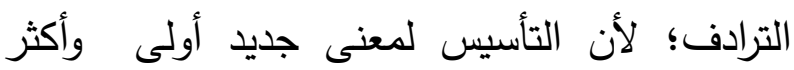

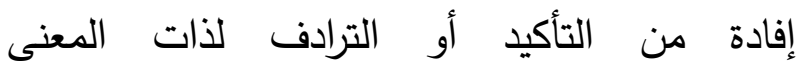

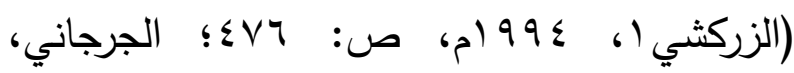

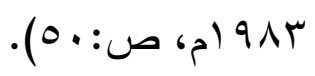

المبحث الثاني: المعنى الاصطلاحي:

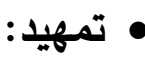

يحسن التقديم بتتبيهين اثثين قبل الشروع في بيان المعنى الاصطلاحي:

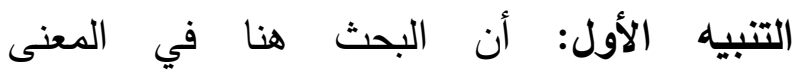
الاصطلاحي عند الفقهاء والمتكلمين أمر منفصل فئل النيل عن مبحث الفاسد والباطل عند الحنفية وعند بقية الإنية الدذاهب الأربعة، فهنا أقرر التعريف للفاسد والباطل

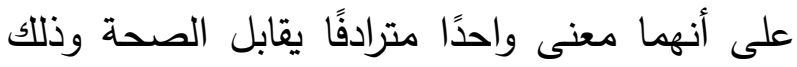
موضح اتفاق بين الفقهاء والدتكلمين.

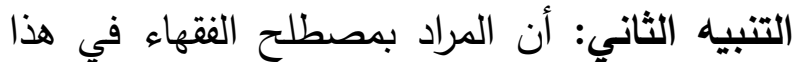
البحث وتحديداً في الفصل الأول: هم الفقهاء من النهاء أتباع الدذاهب الأربعة وغيرهم، والمراد بالمتكلمين: أهل الكلام من الأصوليين والذين قد ينتمي بعضهم الأرئي للدذهب الثافعي أو الحنفي مثلاً. وقد خلط كثير بين الكين هذين المصطلحين من جهة - ولعلّ ما قرّرته هو الفئ

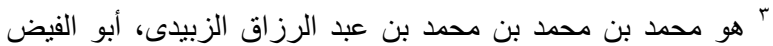

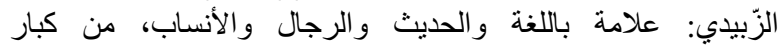
المصنفين. أصله من و اسط في (العراق) ومولده والدئ بالهند ومنشأه في زبيد

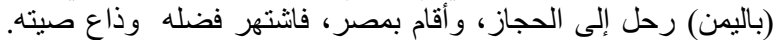
من كتبه (تاج العروس في شرح القاموس )؛؛ (إتحاف السادة المتقين في

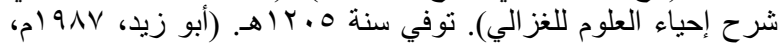

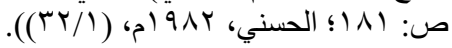

اللحم) إذا أنتن ويمكن الاتنفاع به (الأزهري،

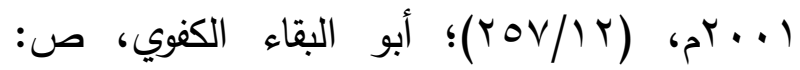

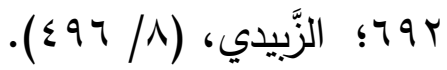

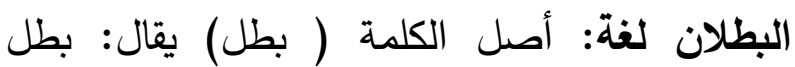

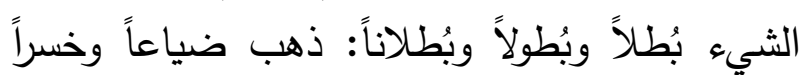

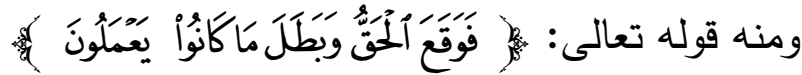

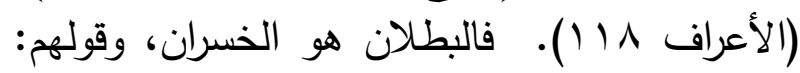
ذهب دمه بطلا: أي هدرا. والإبطال: يقال في إفساد الثيء وإزالته، حقا كان

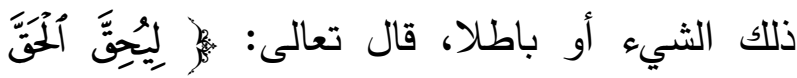

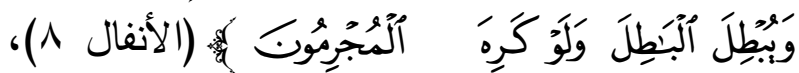
والباطل: ضد الحق وهو ما لا ثبات له عند الفحص النغال .4 cic والباطل: من (بطل اللحم) ، إذا دود وسوس وصار

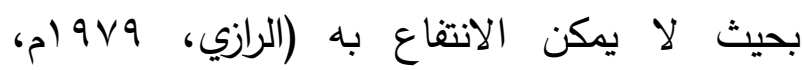

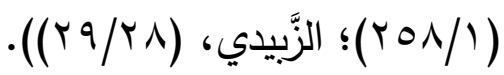
وبعد هذا التعريف اللغوي: هل يقابلان أنهما مترادفان لغويًًا أم أنهما مختلفان؟! الكريف

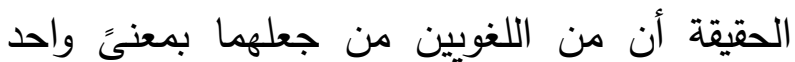

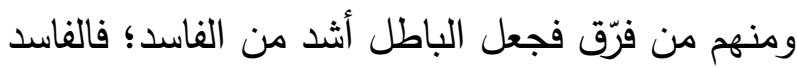

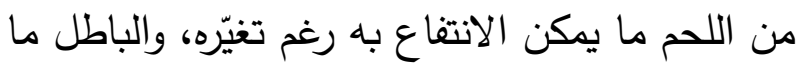

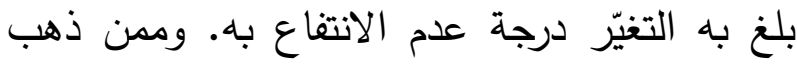

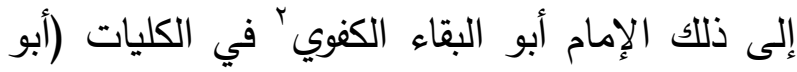

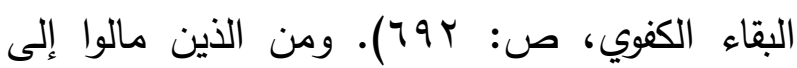

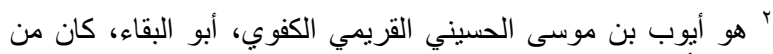



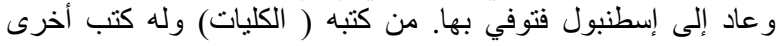

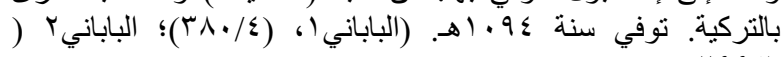
.)( ( $99 /)$ 
عدم سقوط القضاء ، أو عدم موافقة الأمر، وفي

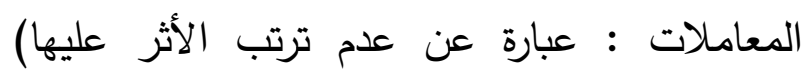

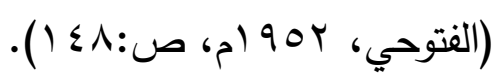

ومنشأ هذه التعريفات للفساد والبطلان في العبادات

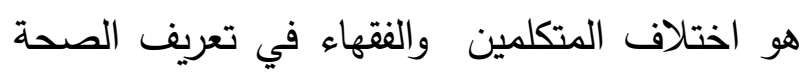
في العبادات والتي هي مقابلة للفساد والبطلان

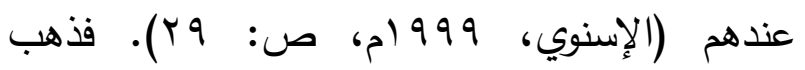
الفقهاء إلى أن الصحة في العبادات : ما أجزأ وأسقط

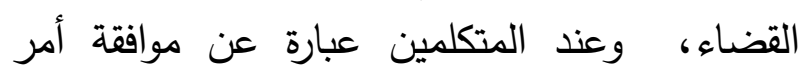

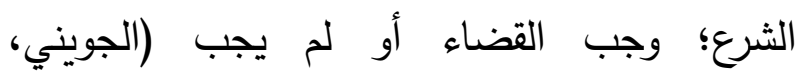

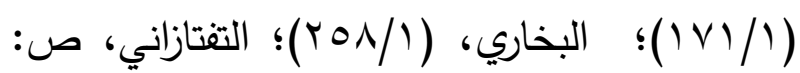
1) (1)، وقد حرر شيخنا الدكتور جبريل هذه المسألة

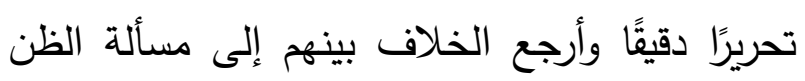
في موافقة الشرع فيرى المتكلمون أن غلبة الظن

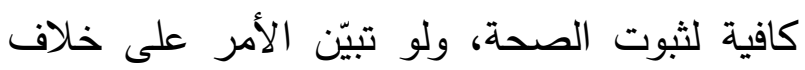

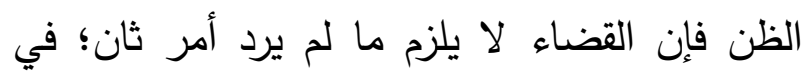

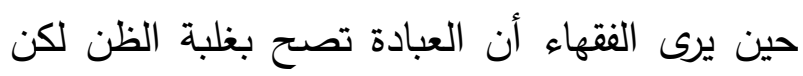

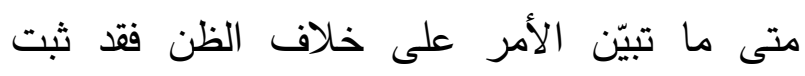

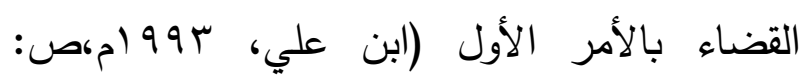
rآ- وسيرد مزيد من الإيضاح لهذه النقطة في الإولي المبحث التالي بإذن الله تعالى).

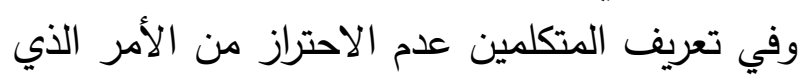

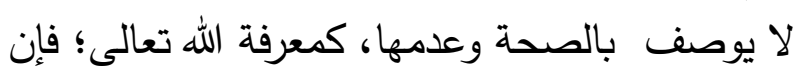
معرفته سبحانه لا تكون إلا موافقةً للشرع، وإلا كانت

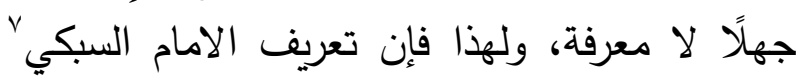

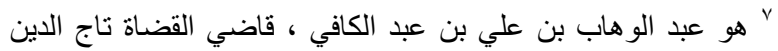

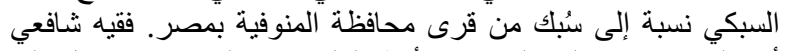

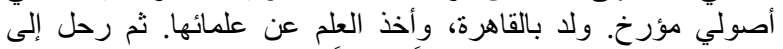



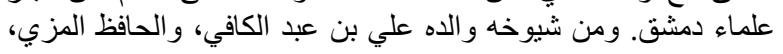

الوارد في كتب الأصول؛ - وبين ما عرف بمنهج

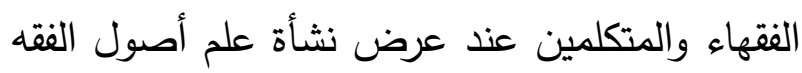

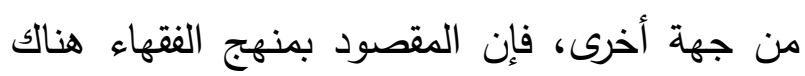

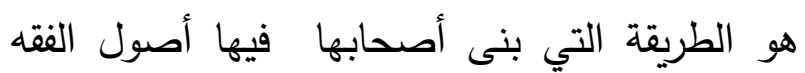
على الفروع الفقهية والتي نسبت للحنفية، ومنهج

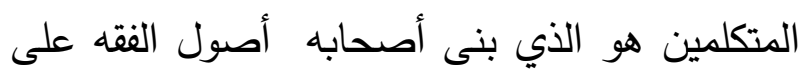

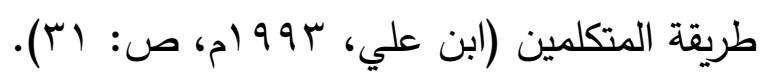

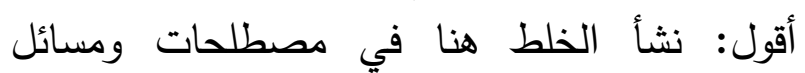

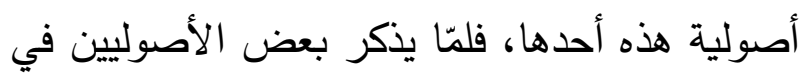

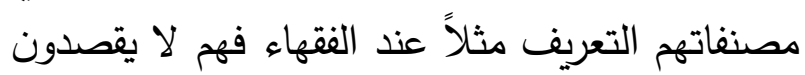
الحنفية تحديداً. وعليه فسأقرر في هذا المبحث تحديداً المقصود بمسطلح الفاسد والباطل عند الفقهاء والمتكلمين على ما تقدم، وسأذكر في المبحث التالي الفرق بين

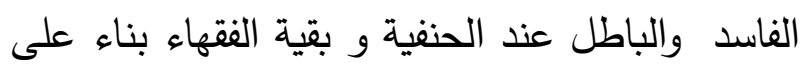
ما هو متفق عليه عند الجميع من كون الفاسد

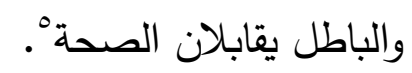
• المعنى الاصطلاحي للفساد والبطلان: ذكر الإمام الفتوحي" رحمه الله ثلاثة تعاريف للفساد لإنطاد

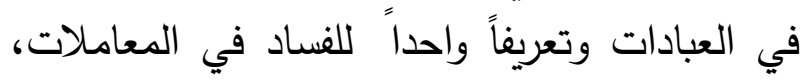

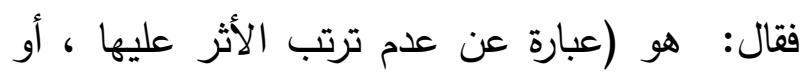

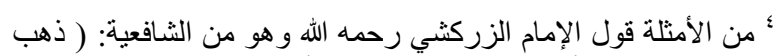

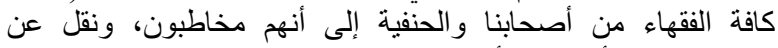


(TV/T)

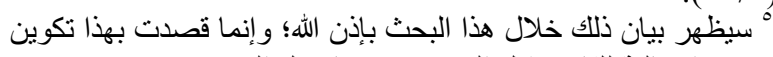

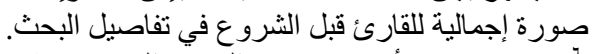

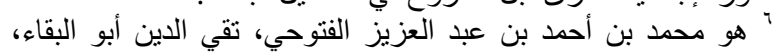

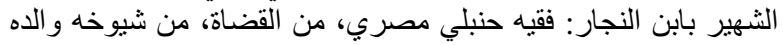

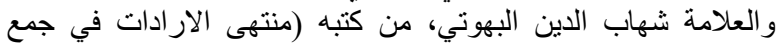

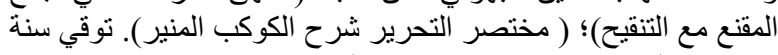

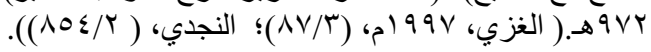


موافقة الفعل للشرع - بغلبة الظن، فمتى ما غلب على ظن المكلف عدم موافقته للشرع فقد حكم على لمعابـ الفعل بالفساد والبطلان، وأيضًا فإن هذا التعريف يصح إطلاقه على الفساد في العبادات والفساد في المعاملات؛ قال الإمام الزركشي '، رحمه الله: ( وعلم من إطلاقه شمول العبادات والمعاملات، فكما أن العبادة إن وقعت مستجمعة الأركان والثروط كانت

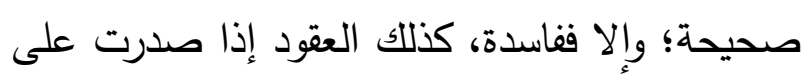

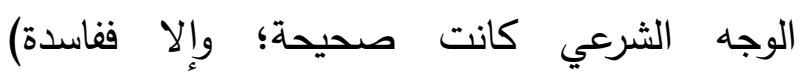

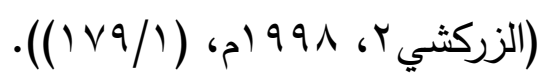

إذاً تعريف الفاسد والباطل عند الباحث هو: مخالفة الفعل ذي الوحهين الشرع. (وقد أشار إلى هذا التعريف الدكتور عبد الكريم

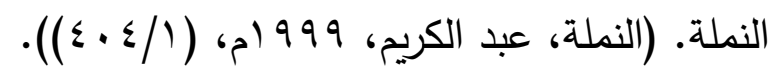

$$
\text { • بيان مفردات التعريف: }
$$

مخالفة الفعل: المقصود بالفعل أي الفعل المطلوب من المكلف سواء كان الطلب على جهة الإيجاب أم

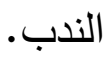

ذي الوجهين: أي الوجه الموافق للشرع والوجه

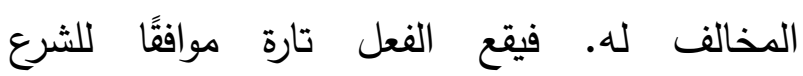
لاستجماعه ما يعتبر فيه شرعا؛ وتارة مخالفا له

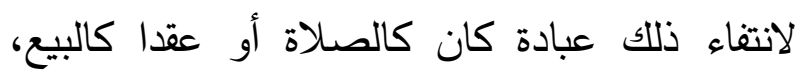
وخرج بهذا القيد ما لا يقع إلا موافقاً للشرع كمعرفة

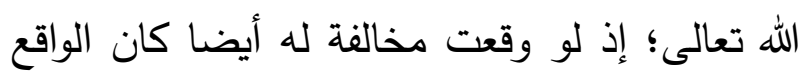
جهالًا لا معرفةً.

'. 'مو محمد بن بهادر بن عبد الله الزركثي أبو عبد الله، بدر الدين:

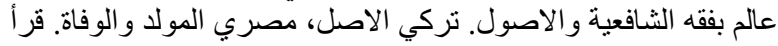

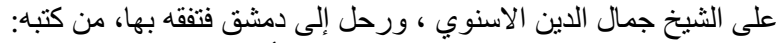

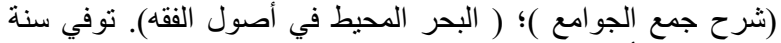

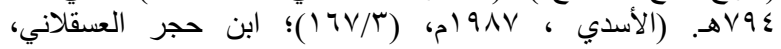

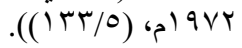

للصحة بقوله: (موافقة ذي الوجهين الشرع) قد احترز

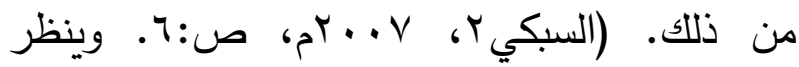

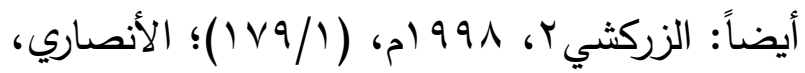

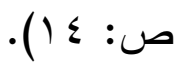
وأما تعريف الإمام الفتوحي للفساد في المعاملات

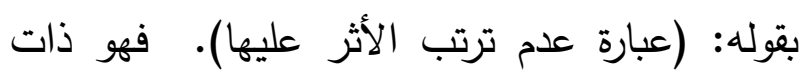

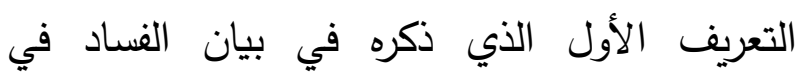

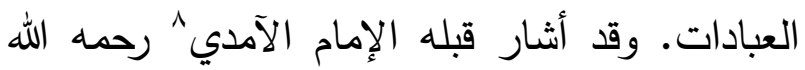

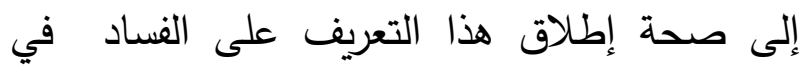

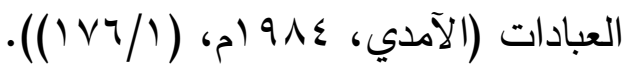

$$
\begin{aligned}
& \text { • التعريف المختار: }
\end{aligned}
$$

تبين مما سبق ذكره في بيان معنى الصحة عند المتكلمين والفقهاء قوة الحجة لدى المتكلمين وذلك فئل فئن

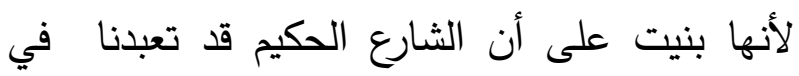

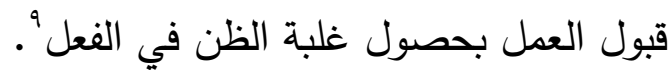

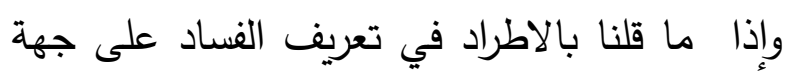
المقابلة لتعريف الصحة فيكون التعريف المختار و الله أعلم هو التعريف المقابل للصحة عند الإمام

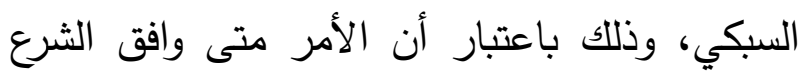
فقد أجزأ وأسقط القضاء، وإنما يعتبر ذلك الكئ - أي وأي

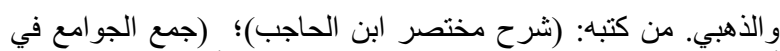

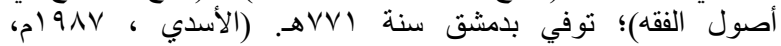

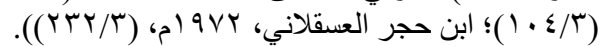

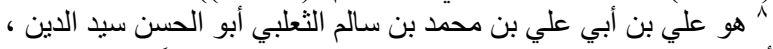

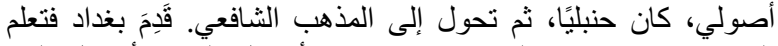

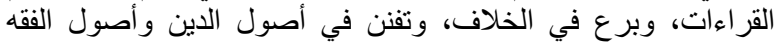

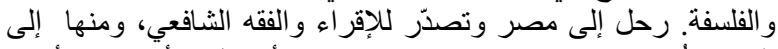

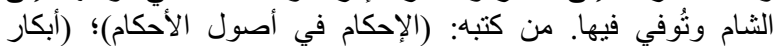

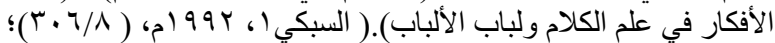

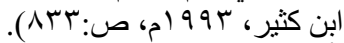

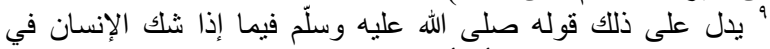

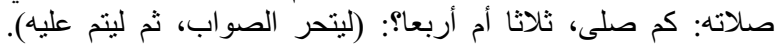

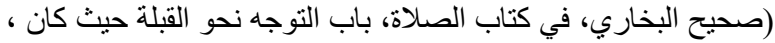

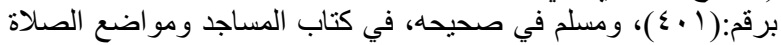

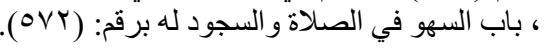


الإنوى، اجن، ص:QVT

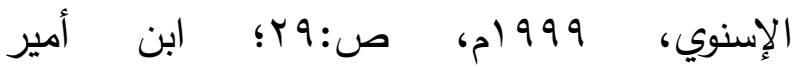

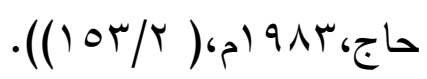

•القول الثاني: ذهب الإمام الزركثي رحمه الله

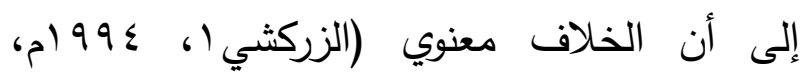

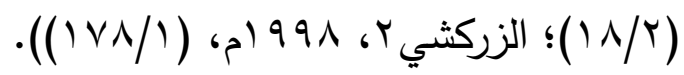

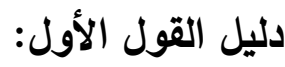

مما يدل على أن الخلاف هو خلاف لفظي: اتفاقهم

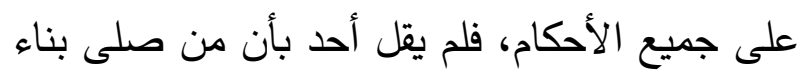


متطهراً بأن القضاء سقط في حقه، وإنما الخلاف في

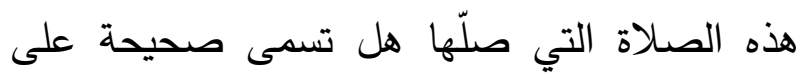
رأي المتكلمين وأن القضاء ثبت بأمر آخر أو أن أن أن

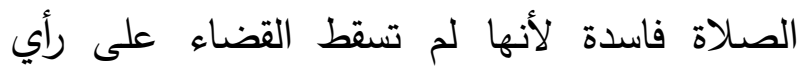
الفقهاء فبقي وجوب القضاء ثابتًا في حقه بالأمر الأراء الأول. قال الإمام القرافي بّا رحمه الله: (اتفق الفريقان على جميع الأحكام، وإنما الخلاف في التسمية؛

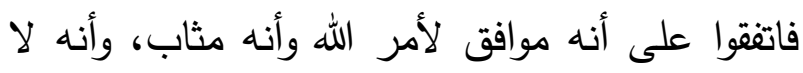
يجب عليه القضاء إذا لم يطلع على الحدث، وأنه النه

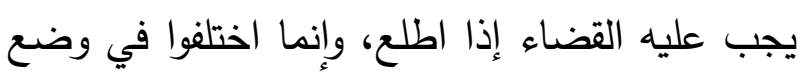

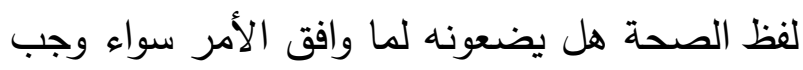

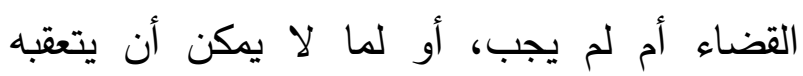

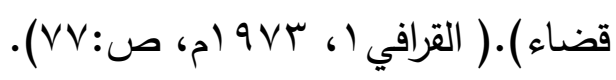

"ا' هو أحمد بن إدريس بن عبد الرحمن، أبو العباس، شهاب الدين

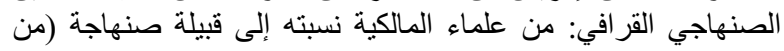



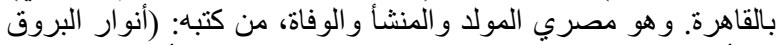

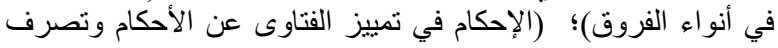

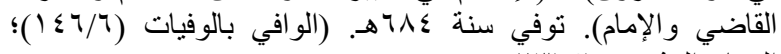

الشرع: بالنصب على الدفعولية، أي: لأمر الثرع. المبحث الثالث: الاختلاف بين الفقهاء والمتكلمين في تعريف الفاسد والباطل: ذكر الإمام الغزالي" رحمد الفيد والباطل: التعريفين المتقدمين

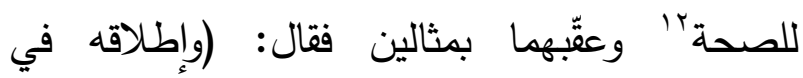
العبادات مختلف فيه فالصحيح عند المتكلمين عبارة

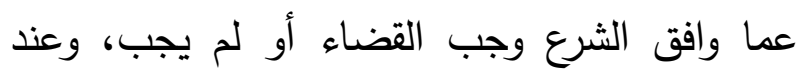

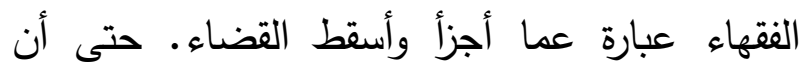
صلاة من ظن أنه متطهر صحيحة في اصطلاح المتكلمين؛ لأنه وافق الأمر المتوجه عليه فئه في الحال

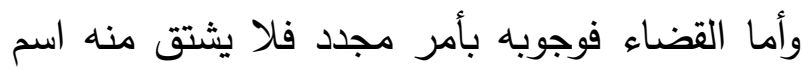

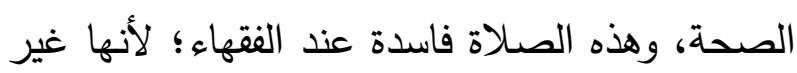

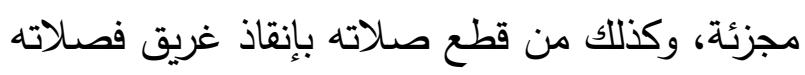
صحيحة عند المتكلم فاسدة عند الفقيه) (الغزالي،

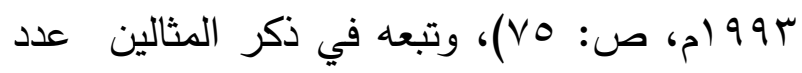
من العلماء في مصنفاتهم.

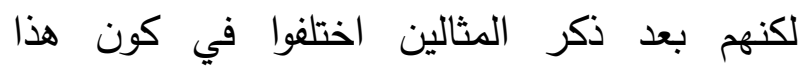

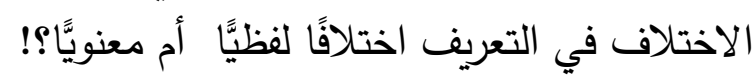

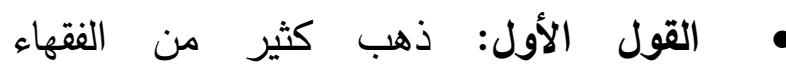
والمتكلمين إلى أن الفرق لفظي، ومنهم الإمام الغزالي ذهي

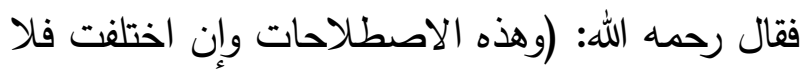

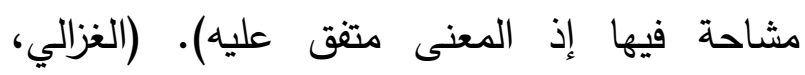

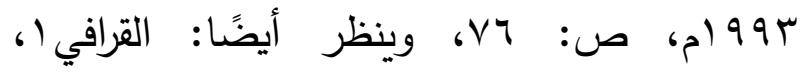

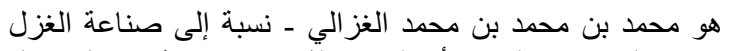

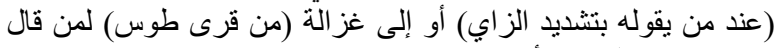

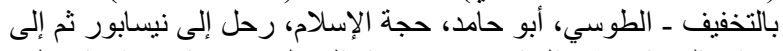

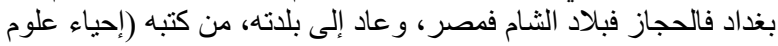

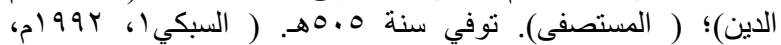

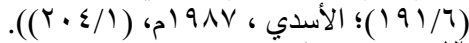

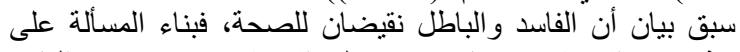
الصحة ونوع الاختلاف فيها ينسحب على الإلى الاختلاف في تعريف الفاسد الفين و الباطل بين الفقهاء و المنكلمين. 


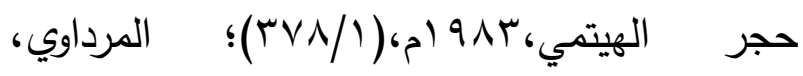
(

Y- إذا تحيّر المجتهد في تحديد القبلة: يرى

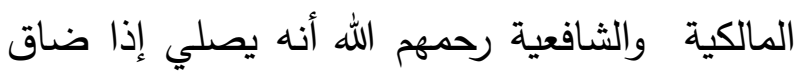

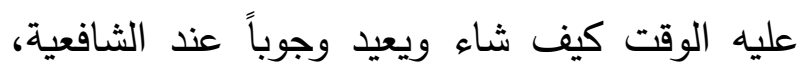
وأما المالكية فذهب البعض إلى عدم القضاء وهو قول الحنفية والمذهب عند الحنابلة، ورأى فريق آخر الخر

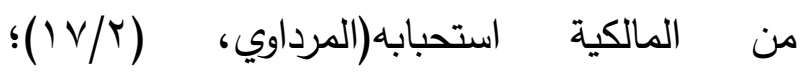

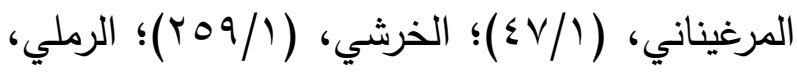
ع ا9 ام،(I//

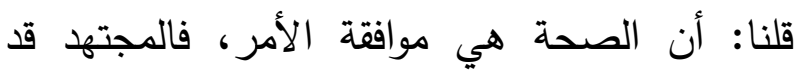

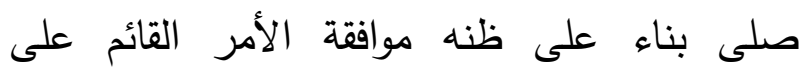

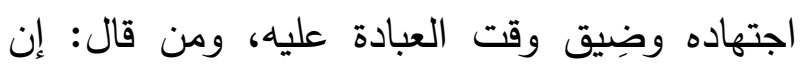
الصحة هي ما أجزأ وأسقط القضاء فعليه الإعادة

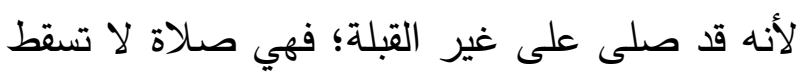

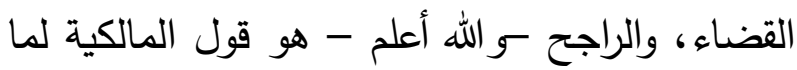
تقدم.

\section{• الترجيح: وبهاتين المسألتين التي ذكرها} أصحاب القول الثاني وارجاع أصلها إلى الاختلاف في التعريف يظهر أن الفرق معنوي وليس لفظياً. الفصل الثاني: الفرق بين الفاسد والباطل في

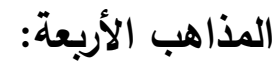
ذكرت في عنوان هذا الفصل عبارة المذاهب الأربعة

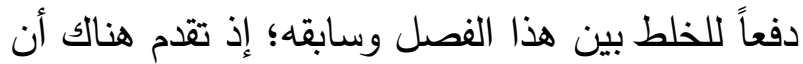

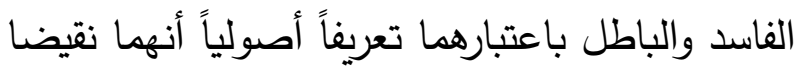
الصحة - على التفصيل المتقدم - أما هنا فسأبحث الفاسد والباطل كمصطلح يذكر في كتب الفروع عند

"' في المسألة أقوال أخرى لبس هنا موضع بسطها؛ إذ المقصود بيان الفئ أثر الآختلاف بين الفقهاء و المتكلمين في التعريف على على المسائل الفقهية.

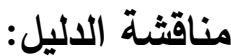

القول بأن الفقهاء متفقين في جميع الأحكام قول غير

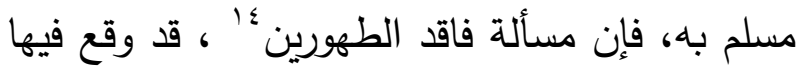

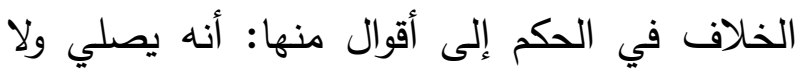
يقضي، ومنها: أنه يصلي ويقضي. والإمام القرافي

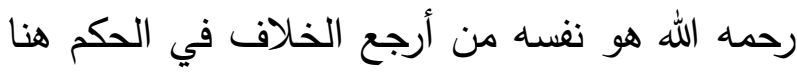
إلى الاختلاف في تعريف الصحة، فقال رحمه الله:

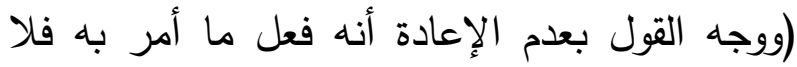

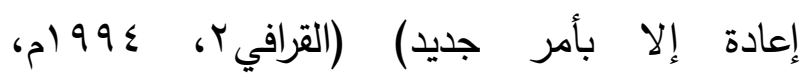
$\cdot((r 0 . / 1)$ أدلة القول الثاني:

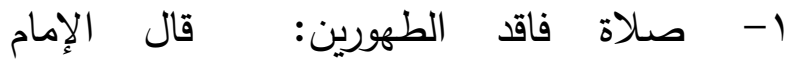
الأصفهاني ' في شرح المحصول: (من لم يجد ماء

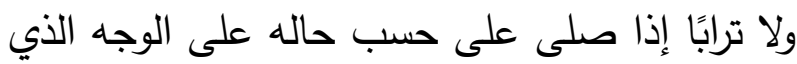
أمر به في ذلك الوقت، فتلك الصلاة صحيحة على حلى الكي اصطلاح المتكلم فاسدة على اصطلاح الفقهاء) (الأصفهاني، مخطوط، اللوح (ع أأ). وفي هذا دلالة على أن الخلاف معنوي وليس لفظيا؛

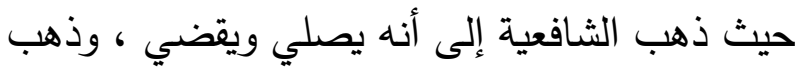

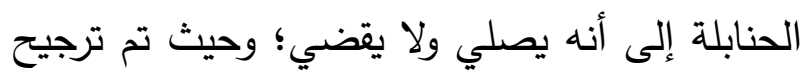

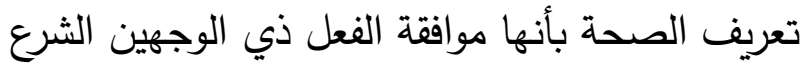

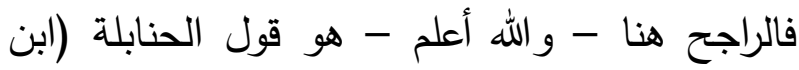



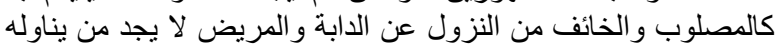

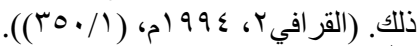



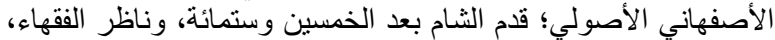

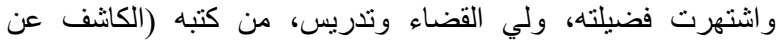

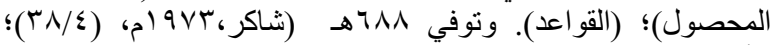

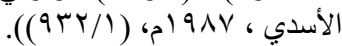


فالإمام السرخسي جعل فعل النذر بأداء الصيام يوم النحر مع كونه منهيا عنه '؛ إلا أنه يقع وفاء به؛ لأن الفساد إنما وقع على وصف الصوم في كونه يوم النحر لا أصل الصوم فإنه مشروع بأصله، بينما نجد أن المتأخرين في المذهب ينصّون على أن الفاسد مرادف للباطل في العبادات، وهم بذلك يوافقون الجمهور ، وهذه بعض الأمثلة: 1- قال ابن نجيم919 رحمه الله: (الباطل والفاسد

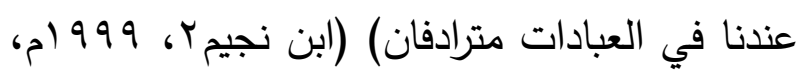

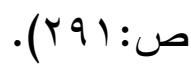
r- قال محمد البخاري ‘ رحمه الله: (والحنيفة كذلك أي يقولون بأن الفساد هو البطلان في العبادات)

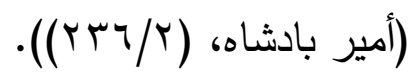
r- قال الإمام ابن عابدين بr رحمه الله: (أئمتنا لم يفرقوا في العبادات بينهما وإنما فرقوا في المعاملات)

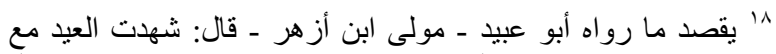

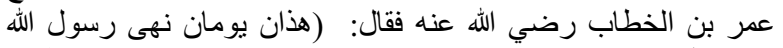

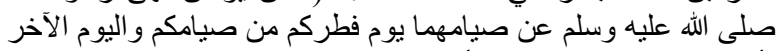

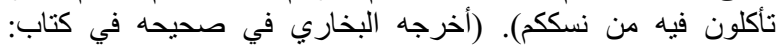

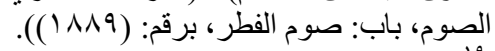
' 19

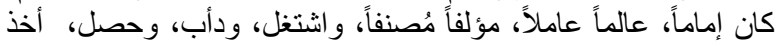



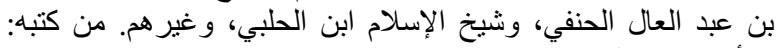

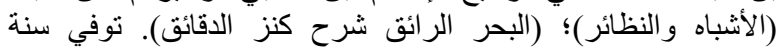

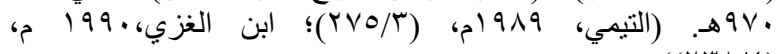

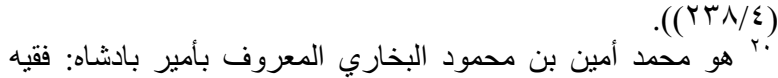

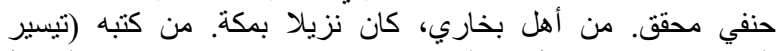

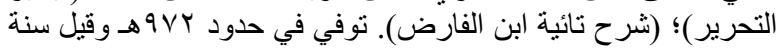

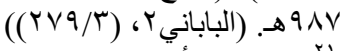

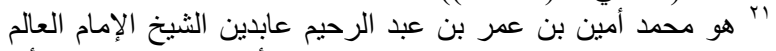

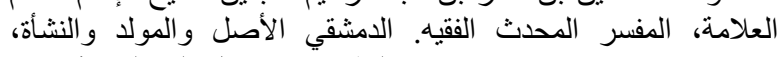

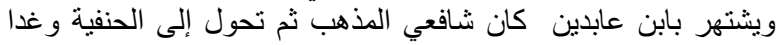

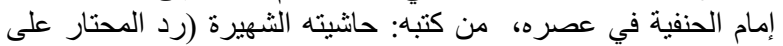

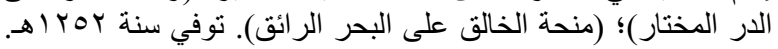

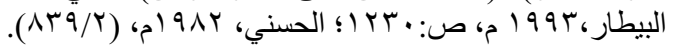

أئمة المذاهب الأربعة تحديداً. وهذه الاصطلاحات جميعها لا تتناقض مع كونها نقيضًا للصحة. المبحث الأول: الفاسد والباطل في العبادات عند كاتهات الحنفية وأثره على الفروع الفقهية: إن المتأمل في كتب الحنفية يجد لأول وهلة أنهم يختلفون في تعبيرهم بالفساد في أبواب العبادات

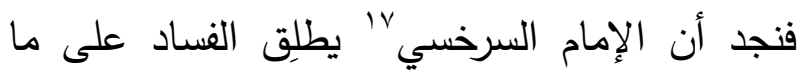
كان مشروعاً بأصله دون وصفه. فيقول رحمه الله في مسألة من نذر أن يصوم يوم النحر: (ولكن

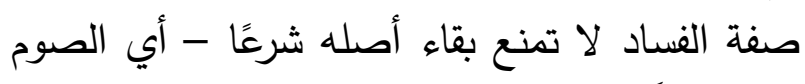

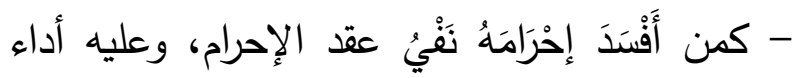
الأفعال شرعًا، وإذا ثبت أن الصوم مشروع في هذي الصغا اليوم فقد حصل نذره مضافا إلى محله فيصح، وليس في النذر ارتكاب المنهي إنما ذلك في أداء الصوم، ولهذا أمرناه بأن يصوم يوما آخر كي لا يكون مرتكباً للنهي، ولو صام في هذه الأيام خرج عن ين ئن موجب نذره؛ لأنه ما التزم إلا هذا القدر وقد أدى هذه الايام جرج كمن قال: لله علي أن أعتق هذه الرقبة وهي عمياء

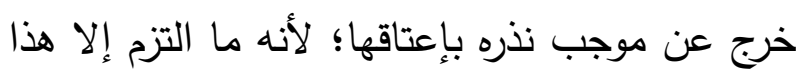

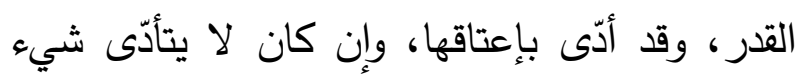
من الواجبات بها، وكمن نذر أن يصلي عند طلوع الشمس فعليه أن يصلي في وقت آخر فإذا صلى في ذلك الوقت خرج عن موجب نذره) (السرخسيكا،

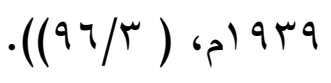

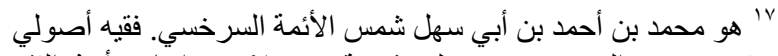

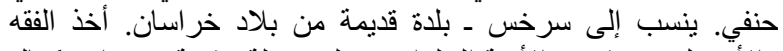

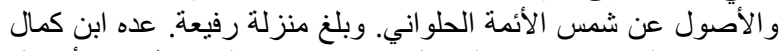

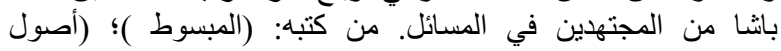

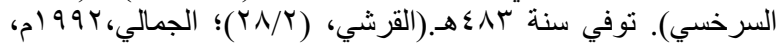

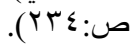


به وصفاً --، فقال رحمه الله: (ومن العبادات النهي

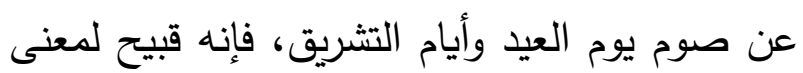

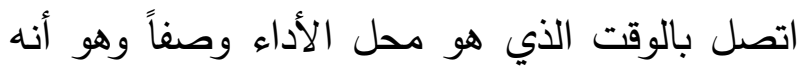

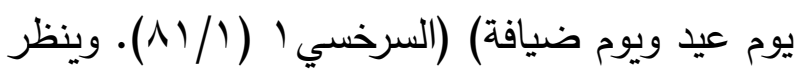

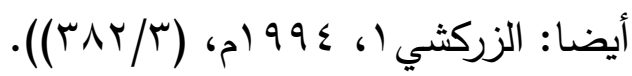

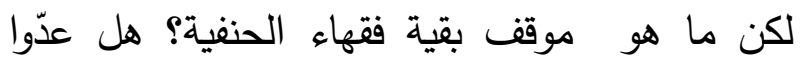
كون الصوم يوم العيد من قبيل الوصف الدجاور

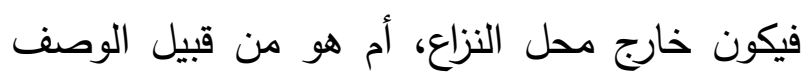

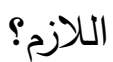

كتب الأصول عند الحنفية بينت أنه من قبيل

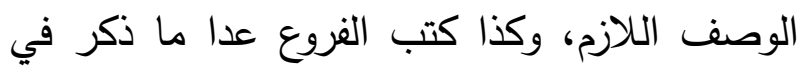

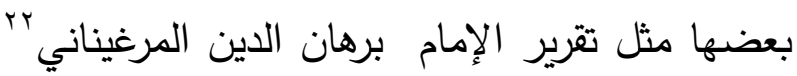
بقوله: (ولنا أنه نذر بصوير الإمام برهان مشروع، والنهي لغيرن الثرغيناني

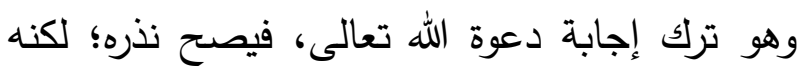



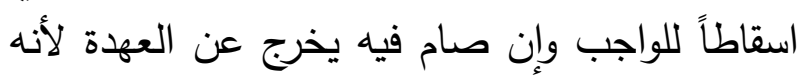

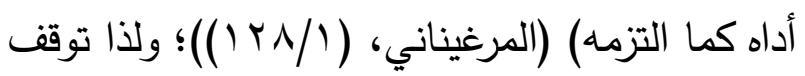


التعارض مع ما ذكر في كتب الأصول، فقال في

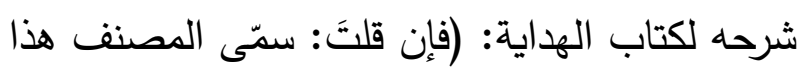

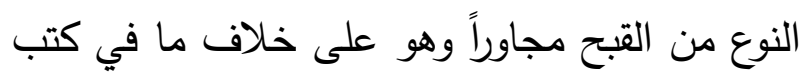

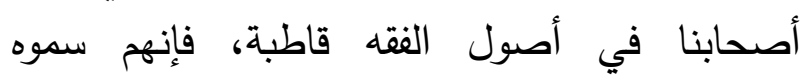
بالمتصل وصفاً، وأما المجاور جمعاً فمثل البيع عند

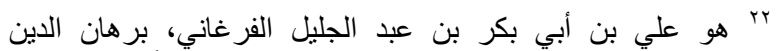

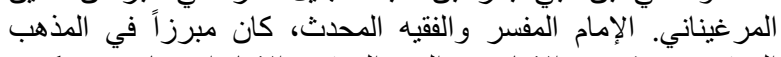

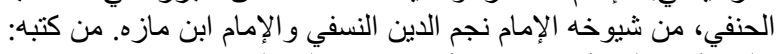

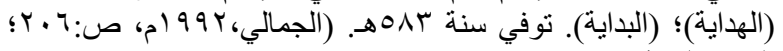

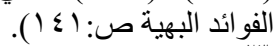

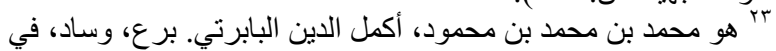

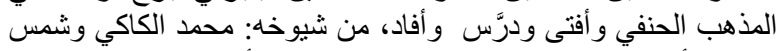

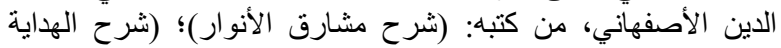

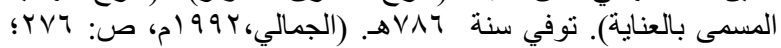

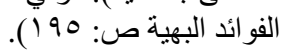

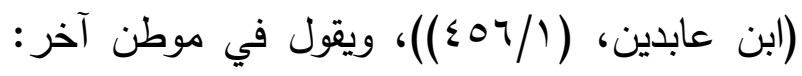

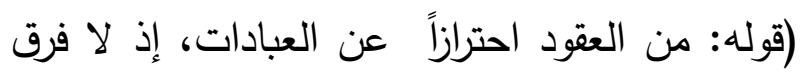

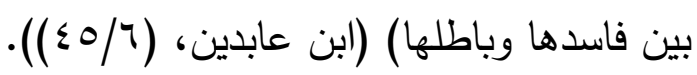

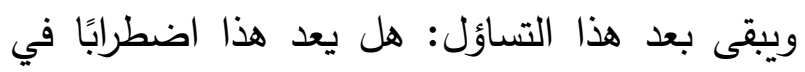

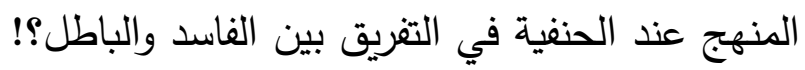

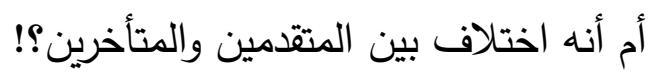

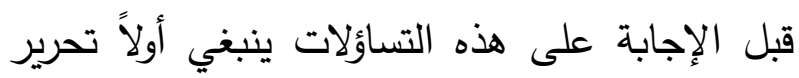

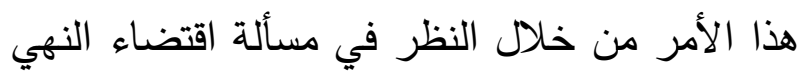

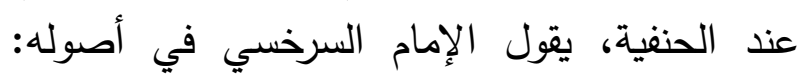
(وإذا تبين أن مقتضى النهي قبح المنهي عنه شرعاً،

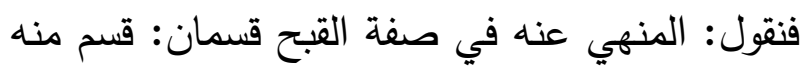
ما هو قبيح لعينه، وقسم منه ما هو قبيح لغيره، وهذا

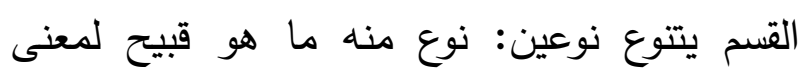

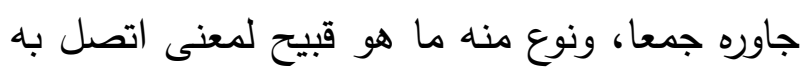
وصفا) (السرخسي ( (1/)).ثم يمضي في التمثيل للقسم الثاني: النوع الأول منه، فقال الهرخال رحمه الله:

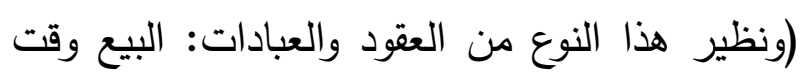

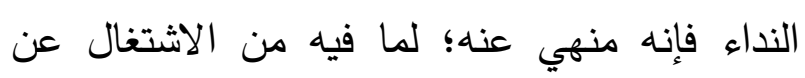

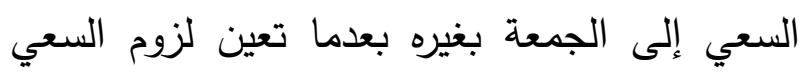

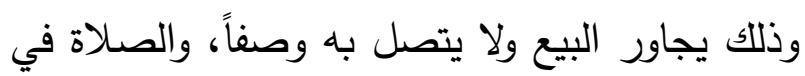

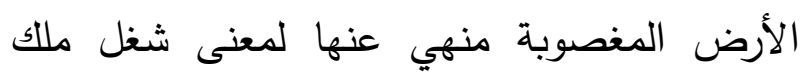

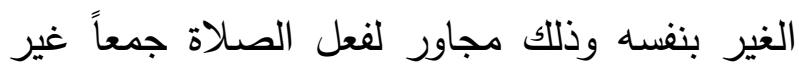

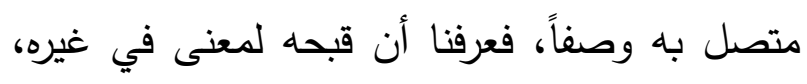

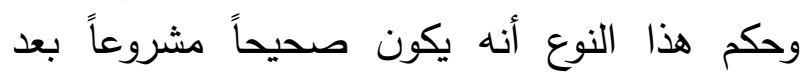

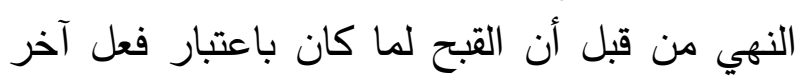

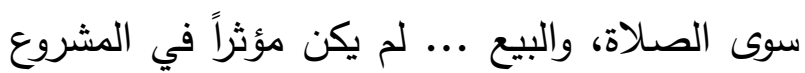

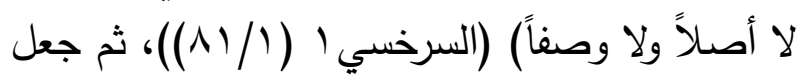

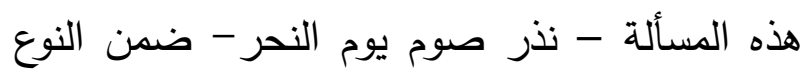

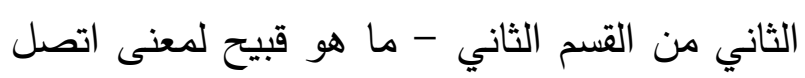


مقتضى هذا بطلان صوم يوم العيد وعدم وجوب القضاء بعد الشروع فيه والإبطال، والحنفية لا يقولون ببطلانه وإن ألزموه بالإبطال والقضاء؛ بل يقولون:

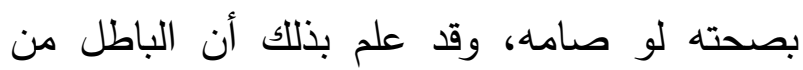
العبادة لا يخص فائت الركن والشرط؛ بل كل ما

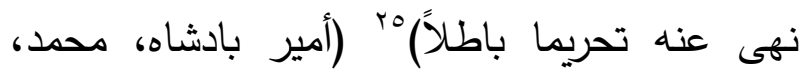
. ((rTY/r)

وبعد هذا يتضح أنه لا فرق بين الفساد والبطلان عند الحنفية في باب العبادات وأن العبادة الفاسدة والباطلة هي ما فات فيها ركن أو شرط، أو نُهي عنها نهيا تحريمياًَ، وكذلك فإن العبادة إذا أدّاها المكلف على في وجه ينهى عنه أداءه بها نظرنا لهذا الوجه؛ فإن كان من قبيل الوصف المجاور كالصلاة في الدار المغصوبة فلا إشكال، وإن كان من قبيل الوصف اللازم كصوم يوم النحر فالعبادة الفاسدة إنما تعتبر في حكم الباطلة بالنظر إلى الثواب الأخروي، فهي فاسدة باعتبار وصفها اللازم وباطلة لعدم ترتب الثواب عليها يوم القيامة وإن صحت بأصلها ؛ وعليه فإن ما ذكره متأخري الحنفية مثل الإمام ابن عابدين في حاشيته من انتظامهم مع الجمهور في نفي الفارق بين الفاسد والباطل في العبادات مطلقاً أمر فيه نظر، وذللك أن تقريقهم في أبواب المعاملات قد ألقى بشيء من ظِلاله حتى على أبواب العبادات، يظهر هذا في نحو مسألة اقتضاء النهي - كما تقدم - فان الفاسد هنا يفارق الباطل في تأثيره عندما يرتبط بأمر آخر تماماً كارتباط النذر بصوم يوم

مانع تعقب شيخنا الدكتور جبريل مهدي هذا القول وردّه بوجوه ثناث.

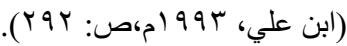

أذان الجمعة. قلتُ: سؤال حسن. والتقصي عن عهدة

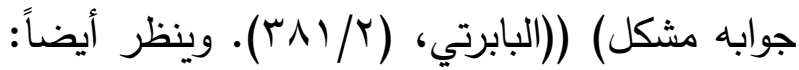

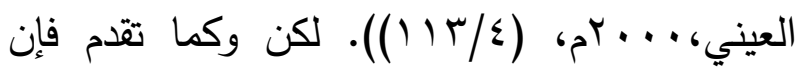
أغلب كتب أصول الحنفية وفروعها بينت أنّ كون إن إنهان الصوم يوم العيد من قبيل الوصف اللازم، وهذا هو عين ما ذهب إليه ابن نجيم في البحر الرائق فقال رحمه الله: (ولهذا فسد صوم يوم النحر وإن ورد النهي فيه لمعنى في غيره؛ لأن النهي فيه باعتبار الوقت والصوم يقوم به ويطول بطوله ويقصر

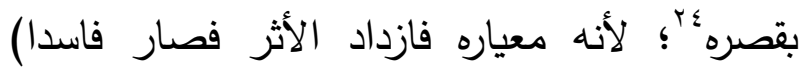

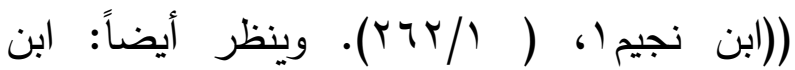
عابدين، (T/T)

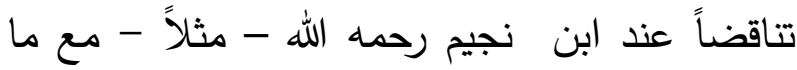
قرره في كتابه الأشباه والنظائر من كون الفساد والبطلان في العبادات مترادفين؟ يجيب على هذا التساؤل محمد البخاري بقوله: (وحاصله أن كل فعل هو من جنس العبادات إذا أتى به المكلف على وجه منهي عنه نهي تحريم فهو

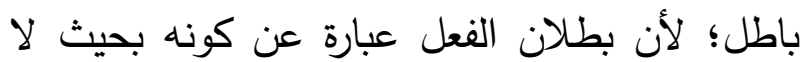
يترتب المقصود منه، ولما كان المقصود من العبادة الثواب واندفاع العقاب لا غير كان المنهي عنه تحريماً باطلاً؛ لعدم ترتب المقصود؛ بخلاف غئ غير العبادة؛ إذ لا يستلزم عدم ترتب الثواب فيه عدم ترتب مقصود آخر كالملك والانتفاع، ومبنى هذا لهاب الكلام: أن المنهي تحريماً لا ثواب له وما يندفع به العقاب، أما إذا جاز ترتب الثواب عليه بدون الانتفاع

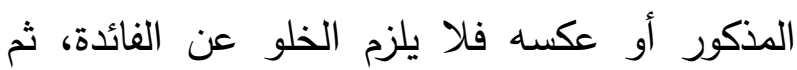


بخلاف الفساد فإنه يلزم بقضاءه من العام المقبل والمضي في حجه الذي أفسده (الجمل،(Y/9 (0)؛

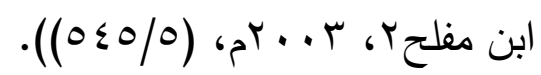

المبحث الثالث: أثر الاختلاف بين الجمهور والحنفية في تحقيق الفرق بين الفاسد والباطل في العبادات: وبعد هذا البيان للفساد والبطلان في العبادات عند الحنفية والجمهور نجد أن هناك اختلاف في بعض الفروع الفقهية بين الفريقين وسببه: هو أن الحنفية

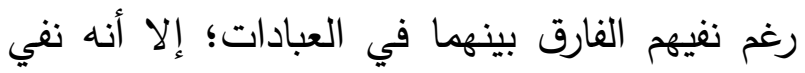
باعتبار الجزاء الأخروي عند وقوع العبادة مرتبطة بوصف منهي عنه لازمها ؛ ولهذا حصل أثر هذا الفرق بين الحنفية والجمهور في مسألة نذر صوم لأرها يوم النحر، وتوضيحه: أن النهي عند الحنفية في هذه المسألة يقتضي القبح في وصفه دون أصله؛ فيكون صحيحاً بأصله فاسداً

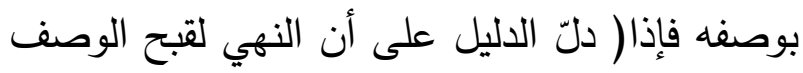
اللازم فلا ضرورة في البطلان؛ لأن صحة الأجزاء والشروط فيه كافية لصحة الشيء وترجيح الصحة بصحة الأجزاء أولى من ترجيح البطلان بالوصف وتف وته

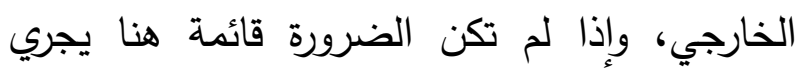
النهي على أصله، وهو أن يكون المنهي عنه موجوداً شرعاً أي صحيحاً) (التفتازاني، (1/1) (1))، فيصح وقوع النذر عليه ويسقط بصومها، وأما الجمهور فإنهم لا يفرقون بين ما يقع النهي فيه على

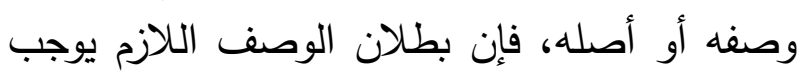

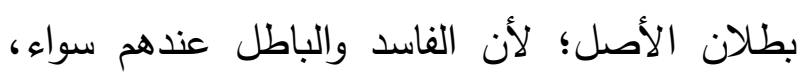

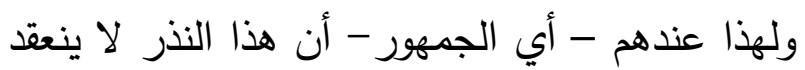
ولا يصح صوم يوم النحر • ((ابن شاس، (ץ/0)؛
النحر، فإنما صح نذره على اعتبار أن النذر قول وليس فعلا، وفعل الصوم يوم النحر قد تقدم فساده أي بطلان وصفه لا أصله، فوقع النذر على القول فيما صح بأصله بَ، فإن صامه فقد أدى نذره كما

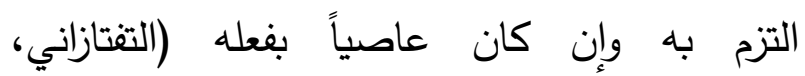
( ) ( ) ()/ . وسيأتي مزيد إيضاح بإذن الله تعالى في المبحث الثالث من هذا الفصل. وبهذا أيضاً - أي اتفاق الحنفية على أنه لا فرق بين الفساد والبطلان في باب العبادات على ما تقدم تقريره - يتضح لنا جليَّا سبب اتفاق الحنفية في معظم الفروع كالمسألة المتقدمة ونذر أداء الصلاة في وقت النهي واستثناء التثريق بين الفساد والبطلان في الحج "rv عن تقريرهم هنا وغير ذللك. المبحث الثاني: الفاسد والباطل في العبادات عند الجمهور وأثره على الفروع الفقهية:

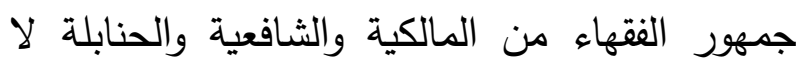
يفرقون بين الفساد والبطلان في العبادات فكلاهما بمعنى واحد وهو نقيض الصحة، فهما إذاً مترادفان

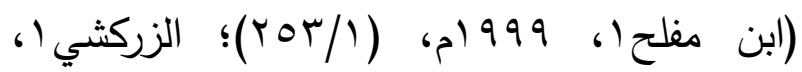

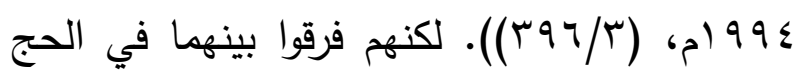
فقالوا: يبطل بالردّة ويفسد بالجماع؛ فيترتب على البطلان هنا عدم وجوب القضاء والمضي فيه؛

بrrr لأن نذر المعصية لا يجوز أصلاً وتجب به كفارة يمين.

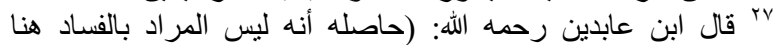

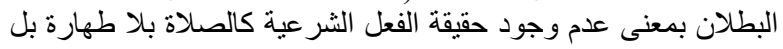

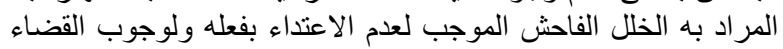

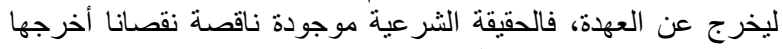

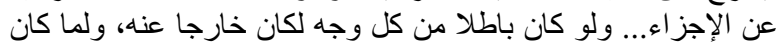



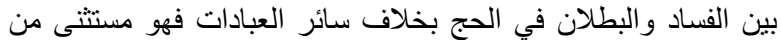

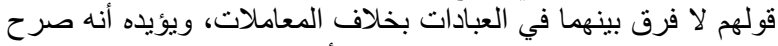

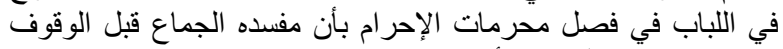

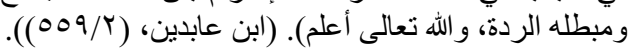


يوم النحر فالعبادة الفاسدة إنما تعتبر في حكم الباطلة بالنظر إلى الثواب الأخروي، فهي فاسدة

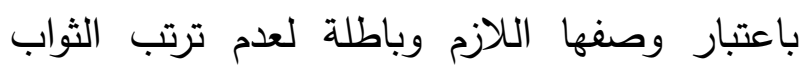
عليها يوم القيامة وإن صحت بأصلها. V- جمهور الفقهاء من المالكية والحنفية والشافعية لا يفرقون بين الفاسد والباطل في العبادات، فكلاهما بمعنى واحد وهو نقيض الصحة. - - الحنفية والجمهور فرّقوا بينهما في الحج فقالوا: يبطل بالردّة ويفسد بالجماع؛ فيترتب على البطلان هنا عدم وجوب القضاء والمضي فيه؛ بخلاف الفساد فإنه يلزم بقضاءه من العام المقبل والمضي في حجه وجه

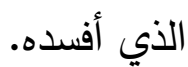

9- هناك اختلاف في بعض الفروع الفقهية بين الحنفية والجمهور وسببه: هو أن الحنفية رغم نفيهم الفارق بينهما في العبادات؛ إلا أنه نفي باعتبار

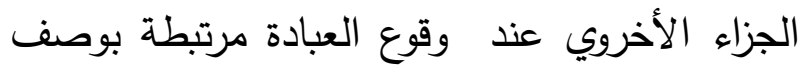
منهي عنه لازمها ؛ ولهذا حصل أثر هذا الفرق بين الحنفية والجمهور في مسألة نذر صوم يوم النحر .

فهرس المصادر والمراجع

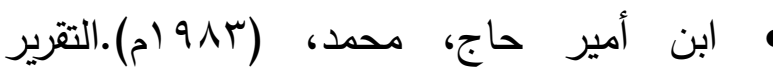
والتحبير، الطبعة: الثانية، بيروت، دار الكتب العلمية. ابن حجر العسقلاني، أحمد، (9VY (م)، الدرر الكامنة في أعيان المائة الثامنة، الطبعة: الثانية، الهند، مجلس دائرة المعارف العثمانية.

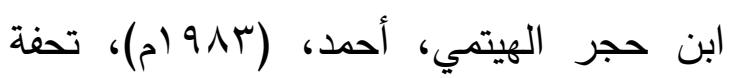
المحتاج في شرح المنهاج ، مصر ، المكتبة التجارية الكبرى .

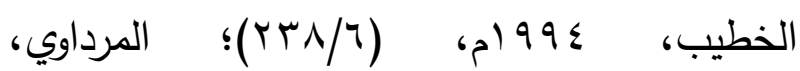
.(( I I T/L) نتائج البحث: وبعد فهذه أهم النتائج التي توصل لها الباحث من خلال هذا البحث: اهث: ا- أن البحث للفاسد والباطل في المغنى الاصطلاحي عند الفقهاء والمتكلمين أرر منفصل عن الفرق بين الفاسد والباطل عند الحنفية وعند بقية المذاهب الأربعة. r- أن المراد بمصطلح الفقهاء في كتب الأصول هم أتباع المذاهب الأربعة وغيرهم، والمراد بالمتكلمين: أهل الكلام. ب- أن الذي ترجح للباحث في المعنى اللغوي للفاسد والباطل هو أنهما غير مترادفين. ع- أن الذي ترجح للباحث في المعنى الاصطلاحي للفاسد والباطل هو: مخالفة الفعل ذي الوجهين الشرع. 0- أن الذي ترجح للباحث - و الله أعلم - أن الخلاف بين المتكلمين والفقهاء للمعنى الاصطلاحي للفساد والبطلان هو خلاف معنوي ينبني عليه أثر فقهي ومن أمثلتها صلاة فاقد الطهورين. 7- لا فرق بين الفاسد والباطل عند الحنفية المتقدمين منهم والمتأخرين في باب العبادات وأن العبادة الفاسدة والباطلة هي ما فات فيها ركن أو شرط، وكذلك فإن العبادة إذا أداها المكلف على وجها ينهى عنه أداءه بها نظرنا لهذا الوجه؛ فإن كان من قبيل الوصف المجاور كالصلاة في الدار المغصوبة فلا إشكال، وإن كان من قبيل الوصف اللازم كصوم 
أبو زيد، بكر، (9NV ) م).طبقات النسابين، الطبعة: الأولى، الرياض، دار الرشد. لرك،

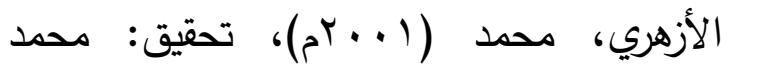
عوض مرعب، تهذيب اللغة، الطبعة: الأولى، بيروت، دار إحياء التراث العربي.

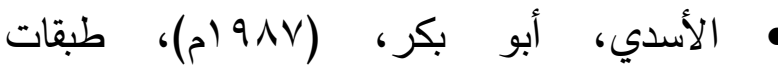
الثافعية، الطبعة: الأولى، بيروت، عالم الكتب. الإسنوي، عبد الرحيم، (999 (م)، نهاية السول شرح منهاج الوصول، الطبعة: الأولى، بيروت، دار الكتب العلمية. - اجة • الأصفهاني، محمد، الكاشف عن المحصول، مخطوط رقم (T/M)، عدد الألواح (YMr)، اسطنبول، المكتبة السليمانية. • الآمدي، علي، (عد9 (م)، الإحكام في أصول

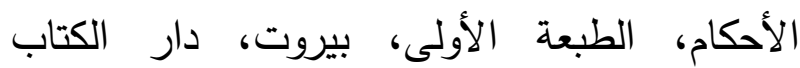
أمير بادشاه، محمد، تيسير التحرير، بيروت،

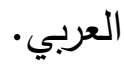

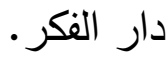
الأنصاري، زكريا، غاية الوصول في شرح لب الأصول، مصر ، دار الكتب العربية الكبرى. الباباني، إسماعيل: ا. إيضاح المكنون في الذيل على كشف الظنون، بيروت، دار إحياء التراث العربي.

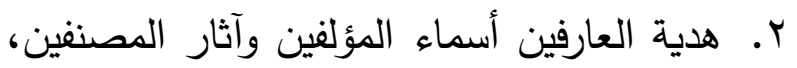
بيروت، دار إحياء التراث العربي. •البابرتي، محمد، العناية شرح الهداية، بيروت،

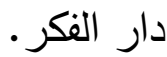
• البخاري، عبدالعزيز، كثف الأسرار شرح أصول البزدوي، بيروت، دار الكتاب الإسلامي.
ابن شاس، عبد الله، عقد الجواهر الثمينة في مذهب عالم المدينة، بيروت، دار الغرب الإسلامي.

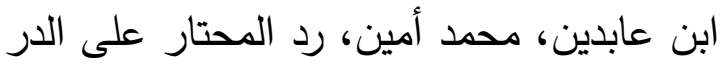
المختار ، ( حاشية ابن عابدين)، بيروت، دار الفكر ابن علي، جبريل، الصحة والفساد عند الأصوليين وأثرهما في الفقه الإسلامي، رئلة رسالة ماجستير، مكة، قسم الشريعة، كلية الشريعة والدراسات الإسلامية، جامعة أم القرى، س إع الهـ

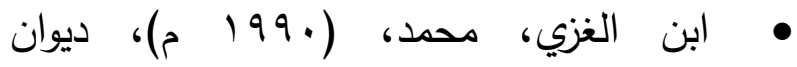

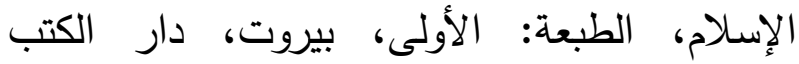
العلمية. ابن كثير، إسماعيل، (ب99 ام)، تحقيق: د

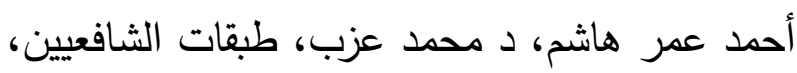
مكتبة الثقافة الدينية. ابن مفلح، محمد:

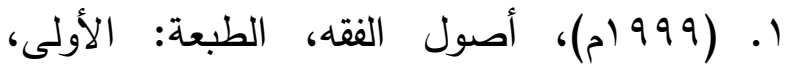
الرياض، مكتبة العبيكان.

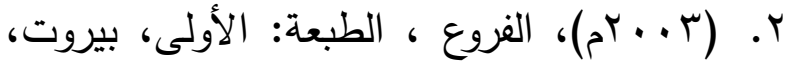
مؤسسة الرسالة. ابن نجيم، محمد: ا ـ البحر الرائق شرح كنز الدقائق، الطبعة: الثانية، بيروت، دار الكتاب الإسلامي. ץ. (999 (م)، الأشباه والنظائر على مذهب إنب أبي حنيفة النعمان، الطبعة: الأولى، بيروت، دار الكتب الاهب العلمية. • أبو البقاء الكفوي، أيوب، تحقيق: عدنان درويش، محد المصري، الكليات معم في المصطلحات والفروق اللغوية، بيروت، مؤسسة الرسالة. 
الخطيب، محمد، (199 (م)، مغني المحتاج

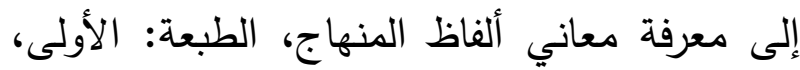
بيروت، دار الكتب العلمية.

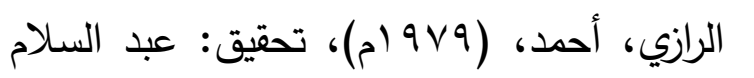

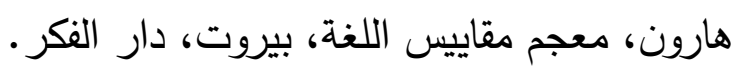

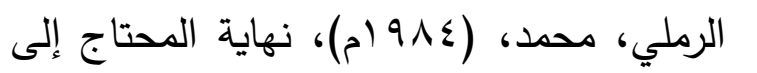
شرح المنهاج، بيروت، دار الفكر،

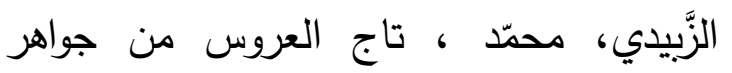

$$
\text { القاموس، دار الهداية. }
$$

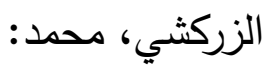

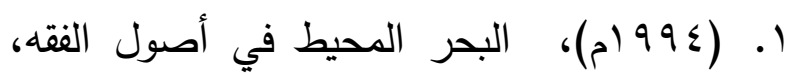
الطبعة: الأولى، دار الكتبي.

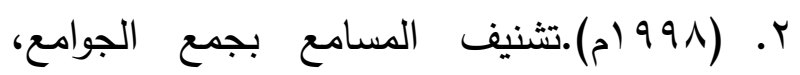
الطبعة: الأولى، مكتبة قرطبة للبحث العلمي وإحياء

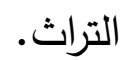

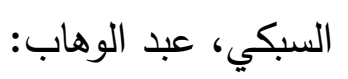

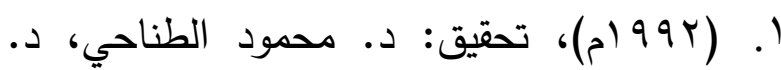

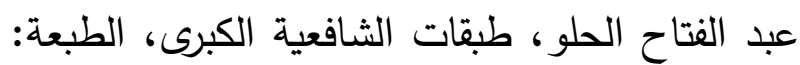
الثانية، هجر للطباعة والنشر والتوزيع.

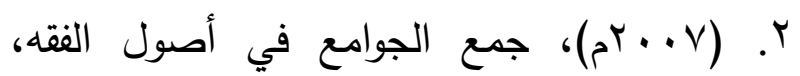
مكة، الرئاسة العامة لشئون المسجد الحرام.

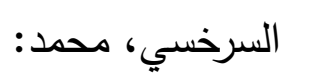

1. أصول السرخسي، بيروت، دار المعرفة.

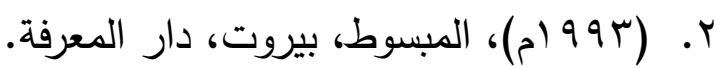

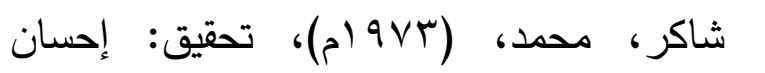

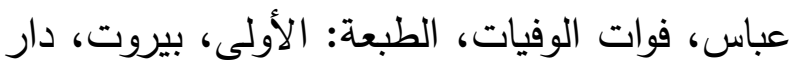

•البخاري، محمد، (9^v (م)، الجامع الصحيح

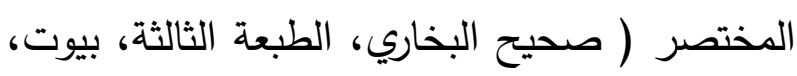

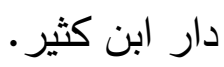

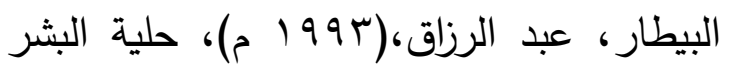

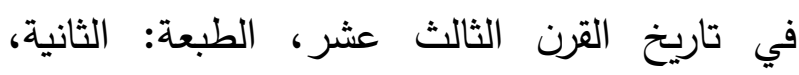

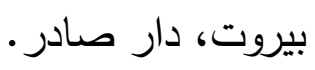

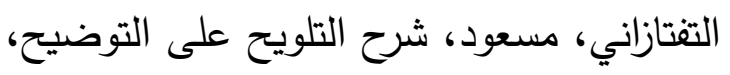
مصر ، مكتبة صبيح. التيمي، تقي الدين، (919 (م)، الطبقات السنية

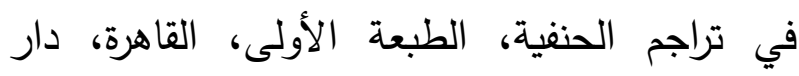
الرفاعي للطباعة والنشر •

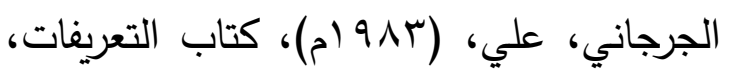
الطبعة الأولى، بيروت، دار الكتب العلمية.


الطبعة: الأولى، دمشق، دار القلم.

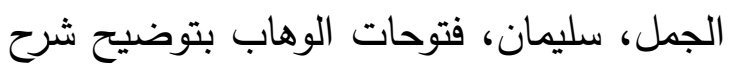
منهج الطلاب المعروف بحاشية الجمل ، دار الفكر.

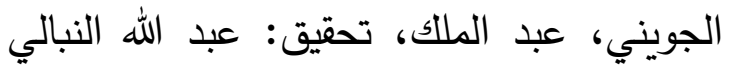
وبشير العمري، التلخيص في أصول الفقه، بيروت:

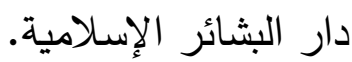

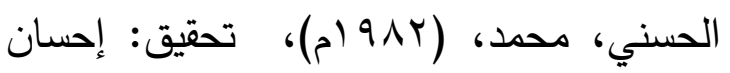
عباس، فهرس الفهارس والأثبات ومعجم المعاجم

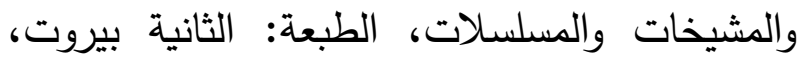
دار الغرب الإسلامي. الخرشي، محمد، شرح مختصر خليل ، بيروت،

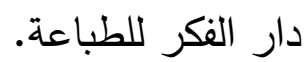




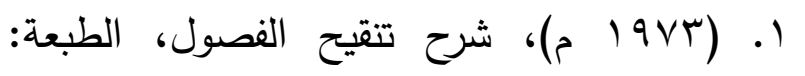
الأولى، شركة الطباعة الفنية المتحدة.



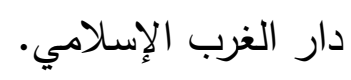

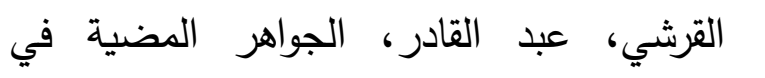
طبقات الحنفية، كراتشي، مير محمد كتب خانه.

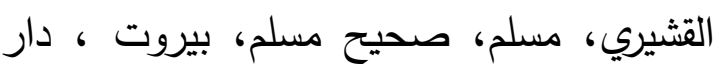

$$
\text { إحياء التراث العربي. }
$$

المرداوي، علي، الإنصاف في معرفة الراجح من الخلاف، الطبعة: الثانية، بيروت، دار إحياء

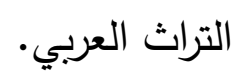


المبتدي، تحقيق: طلال يوسف، بيروت، دار احياء

$$
\text { التراث العربي. }
$$

• النجدي، محمد، السحب الوابلة على ضرائح الحنابلة، بيروت، مؤسسة الرسالة.

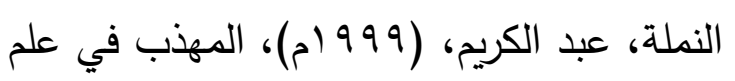
أصول الفقه، الطبعة الأولى، الرياض، مكتبة الرشد.
الشربيني، عبد الرحمن، حاشية الغرر البهية في شرح البهجة الوردية، المطبعة الميمنية.

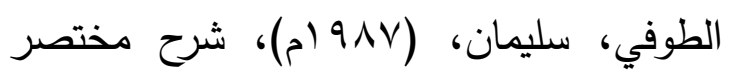
الروضة، الطبعة الأولى، بيروت، مؤسسة الرسالة.

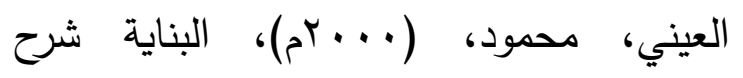

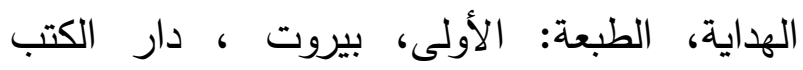
العلمية.

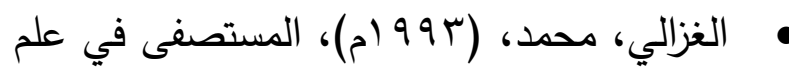

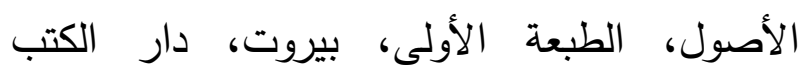
العلمية. • الغزي، محد، (99Vام)، تحقيق: خليل

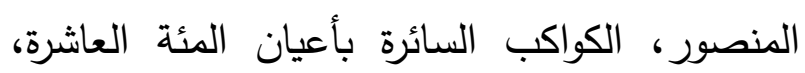
الطبعة: الأولى، بيروت، دار الكتب العلمية.

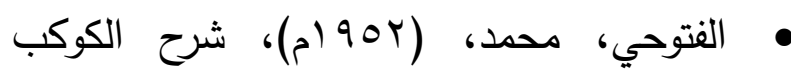

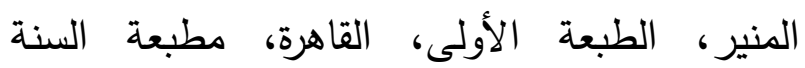
المحمدية. القرافي، أحمد: 


\title{
The effect of the use of the jurists for Alfasid and Albatil in the acts of worship on Juristic Issues
}

\author{
Dr.Ahmed Ali Al-Ghamdi \\ (Assistant Professor of Islamic Culture) \\ University Of Jeddah \\ .Kingdom of Saudi Arabia- Jeddah-tel (966122334444) \\ Ahmadksa1436@gmail.com
}

\begin{abstract}
This research deals with the difference between for Alfasid and Albatil. The researcher compares and prefers what appeared to him after investigation and inference. This research aims to indicate the meaning of Alfasid and Albatil, and based on the definition of a difference between jurists and speakers. This research aims to edit the difference between Alfasid and Albatil in the acts of worship on the four doctrines. And the impact on the branches of jurisprudence. This research has an introduction and two chapters: Chapter I: In a statement of the meaning of Alfasid and Albatil: and under three topics: The first topic: the linguistic meaning. The second topic: the conventional meaning. The third topic: the difference between jurists and speakers in the definition of Alfasid and Albatil. Chapter 2: The difference between Alfasid and Albatil at the four schools of worship. The first topic is: Alfasid and Albatil in the Hanafi and its impact on the jurisprudential branches. The second topic: Alfasid and Albatil in the other schools and its impact on the branches of jurisprudence. The third topic: the impact of the difference between the Hanafi and the other schools in achieving the difference between Alfasid and Albatil in worship.
\end{abstract}

key words:

(Alfasid. Albatil. Alfasad. Albutlan. Speakers. Jurists.). 